\title{
Teza o hybrydyzacji tego, co publiczne i tego, co prywatne w szkolnictwie wyższym oraz jej konsekwencje. Próba krytyki
}

\begin{abstract}
STRESZCZENIE. W niniejszym tekście wskazujemy na problematyczność wysuwanej przez badaczy szkolnictwa wyższego tezy o hybrydyzacji tego, co publiczne i tego, co prywatne w kontekście współczesnych przemian tego sektora. W pierwszej części pochodząca ze słownika liberalnej teorii polityki i klasycznej ekonomii politycznej para pojęciowa tego, co publiczne i tego, co prywatne została przedstawiona i sproblematyzowana w odniesieniu do rzeczywistości szkolnictwa wyższego. W drugiej, zgodnie z metodą analizy glonakalnej zarysowanej przez Simona Marginsona i Garry'ego Rhoadesa, przedstawiono globalne, krajowe i lokalne procesy przyczyniające się według badaczy głównego nurtu tej problematyki do hybrydyzacji porządków tego, co prywatne i tego, co publiczne we współczesnych systemach szkolnictwa wyższego. Część trzecia, stanowiąca podsumowanie artykułu i zawierająca wnioski z analizy, odnosi się krytycznie do wysuwanej przez badaczy szkolnictwa wyższego tezy o hybrydyzacji oraz wskazuje na jej analityczne i praktyczne ograniczenia.
\end{abstract}

SŁOWA KLUCZOWE: hybrydyzacja, szkolnictwo wyższe, prywatne, publiczne, badania nad szkolnictwem wyższym

\section{Wprowadzenie}

Dualizmy bywają niebezpieczne. Poddając się im, ograniczamy naszą zdolność widzenia i poznawania, często upraszczamy obraz złożonych systemów, uniemożliwiając sobie dostrzeganie i rozumienie hybryd czy zjawisk, które nie mieszczą się w zarysowanym przez nie polu. Przede wszystkim jednak utrudniają przeprowadzenie produktywnej zmiany. Ich niewielką użyteczność dostrzegamy zwłaszcza wtedy, gdy chcemy zająć się badaniem tego, co rozciąga się pomiędzy tworzonymi przez nie ideologicznymi biegunami (Marginson 2007a: 310). Wsparte na różnorakich dualizmach założenia przyjmowane w wielu dziedzinach nauki utrudniają produk- 
tywną konfrontację z niedualistyczną rzeczywistością społeczno-gospodarczo-polityczną (Dow 1990: 146). Byśmy jednak mogli je przekroczyć, powinniśmy najpierw nakreślić granice pola wyznaczanego przez zajmujące nas pary pojęć. W niniejszym tekście interesować nas będzie obszar, w którym toczy się znaczna część współczesnych dyskusji dotyczących szkolnictwa wyższego.

Analizowana tu para prywatne - publiczne jest bez wątpienia jedną z najczęściej dyskutowanych opozycji pojęciowych w świecie nauk społecznych. Od dawna wzbudza spory na gruncie filozofii społecznej, teoretycznej socjologii, ekonomii czy nauk politycznych. Nas interesuje jednak opozycja między tym, co publiczne a tym, co prywatne, tak jak problematyzowana jest współcześnie w głównym nurcie badań nad szkolnictwem wyższym. Ograniczenie się do tej dziedziny pozwoli z jednej strony na zachowanie zwięzłości wywodu, z drugiej zaś na przypuszczenie, że przeprowadzona w tych wąskich ramach analiza opozycji prywatne - publiczne będzie kompleksowa i możliwie wyczerpująca.

Sposób, w jaki dokonywana jest konceptualizacja opozycji prywatne - publiczne w odniesieniu do współczesnego szkolnictwa wyższego ma poważne konsekwencje nie tylko dla samych badań naukowych, ale także dla oficjalnej praktyki politycznej dotyczącej tego sektora i - co najważniejsze - strategii oporu tworzonych i realizowanych w jego obrębie.

Choć badania nad szkolnictwem wyższym to wciąż niesamodzielna dziedzina nauki, a która w wielu swoich rozstrzygnięciach posiłkuje się pojęciami, ustaleniami czy teoriami wywodzącymi się z innych dyscyplin ${ }^{1}$, uważamy, że można potraktować je jak swego rodzaju laboratorium. Od kilku dekad testuje się w ich ramach różne sposoby wyjaśniania oparte na nowoczesnej opozycji prywatne - publiczne, próbując w ten sposób uchwycić dynamiczne zmiany, jakim podlega sektor szkolnictwa wyższego, a więc także ład społeczno-gospodarczy, w ramach którego sektor ten funkcjonuje. Wydaje się, że z niepowodzeń, jakie tego rodzaju próby odnoszą na tym polu, pozostałe dziedziny nauk społecznych i humanistycznych mogą wyciągnąc niejedną lekcję.

Problemy, jakich przysparzają badaczom próby objaśnienia złożonej rzeczywistości za pomocą dualistycznego modelu tego, co prywatne oraz tego, co publiczne, omówione zostaną szczegółowo w dalszej części tekstu, niektóre z nich jednak warto zasygnalizować już na wstępie. Obszar współczesnych badań nad szkolnictwem wyższym zostanie potraktowany w taki sam sposób, w jaki Marks traktował dziedzinę klasycznej ekonomii politycznej - jego analiza będzie stanowić punkt wyjścia do rozwinięcia projektu krytycznego ${ }^{2}$.

${ }^{1}$ O problemach powstających w procesie instytucjonalizacji badań nad szkolnictwem wyższym pisze Dominik Antonowicz (2011).

${ }^{2}$ Rozważania zawarte w niniejszym tekście zostały w pełni rozwinięte w książce Uniwersytet jako dobro wspólne. Podstawy krytycznych badań nad szkolnictwem wyższym (Szadkowski 2015), która ukaże się nakładem Wyd. Naukowego PWN. 
Niniejszy tekst składa się z trzech części. W pierwszej z nich para pojęciowa tego, co publiczne i tego, co prywatne została przedstawiona i sproblematyzowana w odniesieniu do rzeczywistości szkolnictwa wyższego. W drugiej części, zgodnie z metodą analizy glonakalnej zarysowanej przez Simona Marginsona i Garry'ego Rhoadesa (2002), przedstawiono globalne, krajowe i lokalne procesy przyczyniające się według badaczy głównego nurtu tej problematyki do hybrydyzacji porządków tego, co prywatne i tego, co publiczne we współczesnych systemach szkolnictwa wyższego. Częśś trzecia, stanowiąca podsumowanie artykułu i zawierająca wnioski z analizy, odnosi się krytycznie do wysuwanej przez badaczy szkolnictwa wyższego tezy o hybrydyzacji oraz wskazuje jej analityczne i praktyczne ograniczenia.

\section{To, co prywatne i to, co publiczne w szkolnictwie wyższym}

Podział na to, co publiczne i to, co prywatne stanowi z pewnością jeden z najważniejszych punktów odniesienia dla wszystkich, którzy zajmują się instytucją uniwersytetu czy systemami szkolnictwa wyższego. Jest „fundamentalnym rozróżnieniem stosowanym w badaniach szkolnictwa wyższego, jak również jednym z tych, które przede wszystkim stanowią punkt orientacyjny w analizach instytucji i krajowych systemów oraz ich ekonomii politycznej” (Enders i Jongbloed 2007: 9). O słuszności przywołanej konstatacji może świadczyć długa lista artykułów naukowych poświęconych temu zagadnieniu oraz liczne monografie (np. Nixon 2011a; Barnett 2012) czy opracowania zbiorowe omawiające konsekwencje oparcia analiz szkolnictwa wyższego na rozróżnieniu prywatne - publiczne (np. Nowotny, Scott i Gibbons 2001; Weber i Bergan 2005; Tierney 2006; Enders i Jongbloed 2007; Rhoten i Calhoun 2011; Pusser, Kempner, Marginson i Ordorika 2012; Filippakou i Williams 2015).

Mimo pokaźnej liczby opracowań trudno mówić o dużym zróżnicowaniu prezentowanych w nich stanowisk. Powszechne rozumienie podziału na to, co prywatne i to, co publiczne czerpie przede wszystkim z neoklasycznej ekonomii oraz liberalnej filozofii politycznej i obciążone jest wszystkimi słabościami właściwymi konceptualizacjom tej opozycji dokonanym na ich gruncie. Sposoby pojmowania tego, co publiczne i tego, co jednostkowe czy prywatne obecne w badaniach nad szkolnictwem wyższym są pojęciową ekspresją „przekształceń przestrzeni uniwersytetów charakterystycznych dla okresu nowoczesności” (Scott 2015: 43), ta zaś, jak wiemy, jest czymś fundamentalnie „dwoistym” (Hardt i Negri 2012: 157) i ambiwalentnym. Badacze i badaczki szkolnictwa wyższego rzadko jednak zwracają uwagę na charakterystyczne dla nowoczesności pęknięcie opisywane przez jej filozoficznych krytyków (Latour 2011). 
Najczęściej przyjmuje się, że podejmowane na całym świecie decyzje dotyczące różnych elementów systemu szkolnictwa wyższego, najogólniej rzecz biorąc, oparte są na zestawach założeń co do tego, czy mają one sprzyjać (czy też już w istocie sprzyjają) w pierwszej kolejności dobru prywatnemu, czy dobru publicznemu, czy mają przyczyniać się przede wszystkim do rozszerzania korzyści prywatnych, których zabezpieczeniem jest indywidualna własność i koordynacyjne mechanizmy rynkowe, czy też dóbr publicznych, którym sprzyjać ma własność publiczna i koordynacja biurokratyczno-państwowa.

To, co prywatne i to, co publiczne tworzą ontologiczną ramę szkolnictwa wyższego, nad którą w kolejnych procesach społecznych, politycznych i ekonomicznych nadbudowuje się to, czego doświadczamy, jako rzeczywistość tego sektora. Nie sposób oczywiście przyjąć, że tak złożony system, jak nauka i szkolnictwo wyższe, realizuje w jednym czasie pojedynczą, jednotorową strategię. Człony opozycji tego, co publiczne i tego, co prywatne stanowią bieguny konkretnego pola sił, pomiędzy którymi rozciąga się codzienność systemów szkolnictwa wyższego i decyzji podejmowanych w ich ramach.

\subsection{Poziomy analizy}

Zastanówmy się, w jakich obszarach ta opozycja może mieć znaczenie i konsekwencje. Jednym ze sposobów uporządkowania problematyki tego, co publiczne i tego, co prywatne w kontekście szkolnictwa wyższego jest zaproponowany przez Olimpię Filippakou (2015: 3) podział na trzy obszary analizy: sferę idei dotyczących instytucji uniwersytetu (poziom ontologiczny), modele zapewniania dostępu do wyższego wykształcenia (poziom dystrybucji) oraz strategie polityczne (policy) (poziom polityczny). Taki podział jest jednak niewystarczający. Nie tylko wydaje się ograniczać rozumienie dynamiki między tym, co prywatne a tym, co publiczne do realiów kształcenia i studiów wyższych realizowanych w instytucji uniwersytetu, ale również sztucznie rozdziela dwa ostatnie poziomy.

Z kolei Jürgen Enders i Ben Jongbloed (2007) wyróżniają cztery podstawowe obszary, w których można analizować dynamikę między tym, co prywatne, a tym, co publiczne w szkolnictwie wyższym. Choć tym razem z pola widzenia znika najbardziej ogólny poziom ontologiczny, to podział zaproponowany przez tych badaczy wydaje się bardzo pomocny, gdy chcemy uchwycić interesującą nas opozycję w jej możliwie najbardziej konkretnym wymiarze.

Po pierwsze, wskazują oni na konieczność analizy aspektów związanych z finansowaniem szkolnictwa wyższego i jego instytucji (Salerno 2005; Jongbloed 2007). Jest to obszar, w którym poszukuje się odpowiedzi na pytania: Skąd i dlaczego w systemie biorą się pieniądze? Kto opłaca możliwość codziennego funkcjonowania 
kadry akademickiej i personelu technicznego czy infrastruktury, takiej jak biblioteki, laboratoria, akademiki czy ośrodki sportowe? Zakładając, że szkolnictwo wyższe i nauka przyczyniają się przede wszystkim do rozwoju dobra publicznego, źródłem ich finansowania są przede wszystkim środki rządowe pochodzące z podatków. Tego rodzaju rozwiązania tracą popularność, choć są jeszcze, szczególnie w Europie, stosunkowo powszechne ${ }^{3}$. Zaczyna jednak dominować przekonanie o istotnym znaczeniu prywatnych korzyści płynących z wykształcenia wyższego. Wynika z tego zazwyczaj dążenie do oparcia finansowania szkolnictwa wyższego na opłatach za studia (częściowych lub pełnych, wprowadzanych w części sektora publicznego lub powszechnie). W konsekwencji niewystarczającego wsparcia publicznego, często przy zachęcie ze strony władz, uniwersytety sięgają również po różnego rodzaju źródła przychodów zewnętrznych, jak komercjalizacja przynależnej im przestrzeni, świadczenie usług badawczych lub dydaktycznych na rzecz lokalnych czy krajowych wspólnot czy przedsiębiorstw. Finansowanie jest jednak tylko jednym z aspektów rozróżnienia na funkcję prywatną i publiczną w szkolnictwie wyższym i to, jak wskazuje Peter Scott (2015: 51), być może nie najważniejszą z nich.

Drugim obszarem, którego badanie postulują Enders i Jonglbloed są sposoby koordynacji i ładu instytucjonalnego czy też modelu rządzenia (governance) stosowane w danym systemie szkolnictwa wyższego (Holley 2006; Tierney 2006). Szuka się tu odpowiedzi na pytania o to, kto i w jaki sposób podejmuje decyzje, a także o procedury, na podstawie których są one podejmowane. Innymi słowy, chodzi o stwierdzenie, kto faktycznie rządzi systemem szkolnictwa wyższego. Kto i za pomocą jakich mechanizmów koordynuje jego działanie? Kto i w ramach jakich procedur wyznacza cele i zadania dla zebranych w danym krajowym systemie szkolnictwa wyższego instytucji? Można powiedzieć, że o ile finansowanie systemu szkolnictwa wyższego stanowi jego krwiobieg, o tyle ład instytucjonalny tworzy kościec, na którym wspiera się cała konstrukcja.

Trzecim obszarem analizy jest sfera własności, to znaczy zarówno układ stosunków własnościowych w sektorze szkolnictwa wyższego (Aaviksoo 2005), czyli to, kto kontroluje instytucje i jak w danym systemie szkolnictwa rozkładają się jego sektory (prywatny i publiczny), jak również podejście do własności wytworów powstających w ramach systemu. Kto ma prawo własności intelektualnej do powstających w sektorze innowacji i wiedzy? Czy są one własnością pojedynczych naukowców, uczelni, na których są oni zatrudnieni, czy może, gdy są opłacane z publicznych pieniędzy, przechodzą do domeny publicznej? W dużej mierze od tego, w jakich warunkach wytwarza się i dystrybuuje wiedzę, zależy charakter danego systemu szkolnictwa wyższego.

${ }^{3}$ Dynamikę zmian w latach 1995-2008 w źródłach finansowania europejskich systemów szkolnictwa wyższego analizują Jongbloed i de Boer (2012). 
Napięcia powstające w tych obszarach można wyjaśnić, przyglądając się sposobom rozumienia i interpretacji ostatniego spośród wskazanych przez Endersa i Jongloeda wymiaru analizy tego, co prywatne i tego, co publiczne w szkolnictwie wyższym, mianowicie sposobu rozumienia korzyści z wyższego wykształcenia i nauki czy też tego, jakiego rodzaju dobra powstają w ich ramach. Kto zatem korzysta z systemu szkolnictwa wyższego? Kto powinien korzystać? Wydaje się, że rozstrzygnięcia dokonane na tym ostatnim poziomie rzutują na wszystkie pozostałe obszary. Dokonuje się ich jednak zawsze w atmosferze konfliktu i ścierania się przeciwstawnych sil.

Kategorie tego, co prywatne i tego, co publiczne zawsze mają charakter historyczny, przez co z jednej strony zawsze są już wynikiem negocjacji, z drugiej zaś pozostają dalej podatne na polityczny spór. Jak zauważają badacze, to właśnie wokół znaczenia tego, co publiczne w szkolnictwie wyższym od lat ma miejsce nieprzerwany konflikt (Enders i Jongbloed 2007: 12; Marginson 2007a; Filippakou i Williams 2015). Nie są to bowiem raz na zawsze ustalone pojęcia, będące naturalnymi określeniami cechującymi różne aspekty nauki i szkolnictwa wyższego. Strony tego sporu przedstawia się często jako zideologizowane typy idealne - na jednym krańcu tworząc obraz neoliberalnych zwolenników wolnego rynku i deregulacji, na drugim stawiając propaństwowych, liberalnych demokratów opowiadających się za budową masowej klasy średniej za pomocą szerokiego dostępu do szkolnictwa wyższego (Newfield 2008).

Simon Marginson (2007a: 309) uważa, że część problemów ze zrozumieniem dynamiki w ramach opozycji prywatne - publiczne wynika z tego, że „konwencjonalny język tego, co publiczne/prywatne zaprojektowany został bardziej dla perswazji i symbolicznego politykierstwa niż dla badań i analizy". W ramach konwencjonalnego rozróżnienia daną instytucję uznaje się za publiczną, gdy powiązana jest z rządem, to znaczy gdy jest własnością państwową, jej finansowanie odbywa się ze środków publicznych, a w procesie koordynacji systemu, którego jest częścią, stosowane są mechanizmy nierynkowe. Natomiast dana instytucja uznawana jest za prywatną, gdy powiązana jest z sektorem przedsiębiorczym, rodziną czy organizacjami społeczeństwa obywatelskiego lub religijnymi, stanowiąc w ten sposób własność prywatną, oraz jest regulowana według zasad rynkowych. Marginson twierdzi jednak, że próba definiowania uniwersytetów w odniesieniu do rozróżnienia na to, co prywatne i to, co publiczne wyłącznie poprzez prawny stosunek ich własności, finansowania bądź rządzenia jest nietrafna i przestarzała (Marginson 2007a: 309). Takie ujęcie, w jego ocenie, nadmiernie upraszcza instytucjonalny obraz szkolnictwa wyższego, bowiem zarówno w prywatnym, jak i w publicznym sektorze wytwarza się dobra publiczne i dobra prywatne, a zrozumienie ich charakteru rzutuje na sposoby finansowania, rządzenia i stosunki własności w szkolnictwie wyższym. 


\subsection{Hybrydyzacja porządków tego, co publiczne i tego, co prywatne}

Enders i Jongbloed stwierdzają, że podział między sferami publiczną i prywatną stał się dziś „niejako niewyraźny, podobnie jak miało to miejsce w innych sektorach społeczeństwa, które uprzednio znajdowały się pod ścisłą publiczną kontrolą" (Enders i Jongbloed 2007: 9). Dwa procesy, w ramach których dokonuje się to zacieranie granic, to 1) daleko idąca delegacja zadań, za które do tej pory odpowiedzialne było państwo i jego agendy, do różnych instytucji trzeciego sektora, 2) postępujący proces włączania elementów właściwych regulacji sfery prywatnej (jak choćby konkurencja, cena czy zdecentralizowane podejmowanie decyzji) w obręb sektora publicznego. „Atrybuty tradycyjnie powiązane z tym, co "publiczne« i tym, co "prywatne « w szkolnictwie wyższym stały się niejasne i kwestionowane, podczas gdy "prywatny « aspekt szkolnictwa wyższego rozszerza swój zasięg i znaczenie" (Enders i Jongbloed 2007: 11). Dla autorów nie tylko rozróżnienie na prywatne/ publiczne stało się niejasne, ale także idea uniwersytetu publicznego została podana w wątpliwość. Stwierdzają oni wręcz, że „uniwersytety stają się dziś hybrydami” (Enders i Jongbloed 2007: 20). Na skutek nieustannych zmian zachodzących na poziomie państwa, społeczeństwa i szkolnictwa wyższego elementy rozróżnienia na to, co publiczne i to, co prywatne w szkolnictwie wyższym stają się coraz bardziej „niestabilne, wieloznaczne i niejasne” (Marginson 2007b: 200).

Już Clark Kerr, analizując powstanie multiwersytetu, wskazywał w 1963 r. na właściwą mu hybrydyczność. Wydaje się, że przyglądając się historii, dostrzeglibyśmy, że nie tyle na przestrzeni lat doszło do zmieszania porząaków tego, co publiczne i tego, co prywatne w instytucji uniwersytetu, ale że w samą naturę tej nowoczesnej opozycji wpisana jest nieredukowalna niestabilność i niejasność. Jeśli rację ma Bruno Latour (2011) i „nigdy nie byliśmy nowocześni”, a nasze binarne opozycje nie radziły sobie z wyjaśnianiem pełnej hybryd rzeczywistości, to dlaczego rozróżnienie na to, co publiczne i to, co prywatne w najważniejszej nowoczesnej instytucji, czyli uniwersytecie, miałoby kiedykolwiek trafnie opisywać sytuację? Jakie są wobec tego przyczyny coraz powszechniejszego przekonania o głębokim pomieszaniu tych dwóch porządków? Czy jest to stan pożądany? Czy istnieją sposoby, by się z tej kłopotliwej sytuacji wydobyć? Próba znalezienia odpowiedzi na te pytania to jedno z zadań niniejszego tekstu, a kolejne jego części będą poświęcone realizacji tego zadania.

Poniżej przyjrzymy się materialnym i empirycznym procesom przyczyniającym się do - diagnozowanego w ramach głównego nurtu badań nad szkolnictwem wyższym - zjawiska zacierania się granic między jasno wyodrębnionymi porządkami tego, co publiczne i tego, co prywatne. Trudno jednak szczegółowo przedstawić wszystkie obszary, w których zachodzą te przemiany. Interesować nas będą zatem 
sposoby przejawiania się hybrydyzacji porządków tego, co prywatne i tego, co publiczne przede wszystkim w odniesieniu do mechanizmów finansowania instytucji szkolnictwa wyższego, ladu instytucjonalnego w obrębie którego funkcjonują, praktyk instytucjonalnych oraz zachowań indywidualnych akademików, jak również mechanizmów wpływających na status własnościowy wytworów sektora szkolnictwa wyższego. Przyjrzymy się tym procesom na trzech poziomach. Najpierw analizie zostaną poddane procesy hybrydyzacji zachodzące na poziomie globalnym. Następnie przyjrzymy się zjawiskom o charakterze krajowym, ograniczonym ramami narzucanymi przez państwo narodowe w zakresie regulacji i koordynacji danego krajowego sektora szkolnictwa wyższego. Wreszcie, zejdziemy na poziom lokalny, gdzie analizowane przekształcenia bezpośrednio wpływają na funkcjonowanie instytucji i są doświadczane na co dzień przez poszczególnych akademików. Badane zjawiska i procesy nie ograniczają się jednak swoim oddziaływaniem tylko do jednego z tych poziomów, lecz przenikają się i współkształtują. Relacje zależności zachodzą więc nie tylko z „góry na dół” (od globalnego, przez krajowy, do lokalnego poziomu), ale we wszystkich możliwych kierunkach (o glonakalnym sprawstwie zob. Marginson i Rhoades 2002).

\section{Hybrydyzacja tego, co publiczne i tego, co prywatne na poziomie globalnym}

Szanse na generowanie dodatkowych przychodów otwarte przed instytucjami szkolnictwa wyższego w ramach postępującej globalizacji sektora nie ograniczają się wyłącznie do podmiotów komercyjnych i nastawionych na zysk. Po pierwsze, wzmacniają całe krajowe systemy (wraz z ich publicznym sektorem), jak ma to miejsce choćby w Stanach Zjednoczonych, Wielkiej Brytanii czy innych krajach anglosaskich, gdzie przyjmuje się rocznie setki tysięcy studentów, którzy opłacają swoją naukę poprzez czesne. W przypadku wskaźnika PKB Australii poprzez rozwinięte i aktywnie działające w obszarze Azji Wschodniej instytucje szkolnictwa wyższego, zabiegające o opłacających swoją naukę międzynarodowych studentów, wypracowywane jest ponad 22 mld dolarów rocznie. Sytuacja taka nie byłaby z pewnością możliwa, gdyby nie głębokie reformy zrealizowane w paradygmacie Nowego Zarządzania Publicznego, które zrealizowano w tych krajach w latach 80. i 90. XX wieku. Po drugie, uczelnie publiczne z krajów i systemów ulokowanych centralnie w ramach globalnego podziału pracy prowadzą w ustanowionej porozumieniem GATS sferze wolnego handlu usługami edukacyjnymi aktywną politykę nastawioną na generowanie zysku. W sferach tego rodzaju aktywności, szczególnie w kampusach zamiejscowych, warunki pracy pracowników akademickich nie są regulowane przez krajowe prawo pracy, co prowadzi często do nadużyć i postępującej prekaryzacji stosunków pracy (Ross 2011). Obszar globalnej i transnarodowej 
aktywności w ramach kapitalizmu akademickiego (Kauppinen 2012: 547; Slaughter i Cantwell 2012), podobnie jak towarzyszący jego powstaniu wzrost znaczenia transnarodowych organizacji ukierunkowanych na regulowanie i standardyzowanie rzeczywistości szkolnictwa wyższego z poziomu globalnego, czy powstanie globalnych rankingów uniwersytetów są zatem sferami, w których zachodzą procesy przyczyniające się do hybrydyzacji porządków tego, co publiczne i tego, co prywatne (Kwiek 2006: 126; Leslie i Slaughter 1998; Marginson 2007b; Enders i Jongbloed 2007; Musiał 2013: 108).

Coraz większe zaangażowanie w różnego rodzaju globalne rynki edukacyjne oraz presja związana z konkurencją globalną z pewnością mogą stanowić zagrożenie dla cieszących się niegdyś jasno określoną tożsamością publicznych instytucji szkolnictwa wyższego. $Z$ tego właśnie względu niektórzy badacze szkolnictwa wyższego postulują ich „ponowne upublicznienie” (republicizing) (Slaughter i Rhoades 2004: 56-57; Calhoun 2006; Marginson 2006). Taka perspektywa nie jest jednak wolna od ograniczeń, zakłada bowiem, że zatarte granice między tym, co prywatne a tym, co publiczne można przywrócić w dawnej formie. O tym jednak, jak trudny w realizacji jest ten postulat, może przekonać uważna analiza procesów hybrydyzacji postępujących na dwóch pozostałych poziomach organizacji szkolnictwa wyższego.

\subsection{Hegemonia}

Wydaje się, że na posłużenie się w analizie typami idealnymi procesów i dyskursów pozwala potwierdzić założenie o hegemonicznej pozycji zajmowanej w sektorze szkolnictwa wyższego nieprzerwanie od lat 60. XX wieku przez system amerykański czy mówiąc ogólniej: anglosaski. W krajobrazie globalnego, krajowego i lokalnego szkolnictwa wyższego możemy dostrzec hegemoniczne normy, wartości czy języki, jak również formy instytucjonalne, w których owe normy są realizowane. Podobnie jak Simon Marginson i Imanol Ordorika (2011; por. Marginson i van der Wende 2007: 22), hegemonię w kontekście szkolnictwa wyższego rozumiem za Antoniem Gramscim (1961a: 531) jako „kompromisową równowagę”, nieustannie powstający i przezwyciężany „stan niestałej równowagi (w granicach prawa) pomiędzy interesami grupy zasadniczej i grup zależnych, stany równowagi, w których interesy grupy panującej przeważają, ale tylko do pewnego stopnia, a nie aż do zupełnej wyłączności interesów ekonomiczno-korporacyjnych” (Gramsci 1961a: 534). W obszarze szkolnictwa wyższego i nauki tego typu równowaga zachowywana jest choćby w ramach dyskursu o uniwersytecie jako motorze gospodarek opartych na wiedzy. Korzyści czerpane z dynamicznego rozwoju nauki i edukacji wyższej dokonującego się we wszystkich krajach na świecie nie są w skali globalnej dzielone sprawiedliwie. Dominujące systemy i kraje nie tylko przyciągają najwybitniejszych badaczy i najzdolniejszych studentów, lecz są również w stanie sprawnie wykorzy- 
stywać czy prywatyzować wiedzę i osiągnięcia wytwarzane niekiedy „przypadkiem” w systemach zależnych. Oczywiście nie podważa to faktu, że niektóre korzyści płynące z rozwoju opartego na wiedzy nie dają się oddzielić od obszaru, w którym się on dokonuje. Ponadto w ramach tej kompromisowej równowagi zbudowanej wokół rozwoju gospodarek opartych na wiedzy „grupa panująca” jest w stanie dostarczać artykułów wiedzy i technologii wytwarzania wiedzy „grupie zależnej”, wzmacniając w ten sposób swoją pozycję i przedłużając panowanie w obrębie systemu. Jak twierdzi Gramsci:

[...] niewłaściwie jest interpretowanie konkretnego stawiania kwestii hegemonii tak, jakby miało ono oznaczać podporządkowanie grupy hegemonicznej. Samo istnienie hegemonii zakłada z góry liczenie się z interesami i dążeniami grup, nad którymi owa hegemonia się rozciąga, oraz wytworzenie pewnej kompromisowej równowagi, znaczy to, że grupa kierownicza ponosi pewne ofiary w dziedzinie ekonomiczno-korporacyjnej. Oczywiście ofiary te i ten kompromis nie mogą jednak dotyczyć spraw zasadniczych, chociaż bowiem jest to hegemonia etyczno-polityczna, nie może nie być zarazem hegemonią ekonomiczną i musi opierać się na decydującej roli, jaką grupa kierownicza odgrywa w ośrodku dyspozycji gospodarczej (Gramsci 1961a: 531-532).

Interes hegemonicznych systemów szkolnictwa wyższego, czy też amerykańskiego systemu-hegemona, dominującego w polu akademickim wraz z grupą swych anglosaskich sojuszników, jest w pełni zabezpieczony. Jednocześnie właściwy procesom akumulowania przewagi w nauce efekt św. Mateusza (Merton 1968), polegający na tym, że już uposażeni będą się jeszcze bardziej bogacić, a biedni jeszcze bardziej ubożeć, sprawia, że trudno sobie dziś wyobrazić, zrodzoną na gruncie logiki rządzącej polem naukowym, sposób na położenie kresu amerykańskiej hegemonii.

Gramsci w latach 20. XX wieku sceptycznie podchodził do „amerykanizmu” (1961b), traktując go jako jedynie przedłużenie oraz intensyfikację kultury i cywilizacji europejskiej, nieniosącą w sobie szczególnie oryginalnej formy i treści. Jednak Marginson i Ordorika są przekonani, że mimo ogłaszanego przez wielu teoretyków i badaczy upadku amerykańskiego unilateralizmu i hegemonii (Hardt i Negri 2012: 316-321), sam „amerykanizm” jako hegemoniczna formacja kulturowa, wzmacniana niegdyś dzięki kulturze masowej, obecnie zaś coraz bardziej bazująca na elitarnych uczelniach Ligi Bluszczowej (Ivy League), nabrał dziś swoistej treści. Co więcej, w sektorze szkolnictwa wyższego jego hegemonia globalna jest szczególnie wyraźna i trudna do podważenia, a czołowe instytucje sektora są napędzane przez amerykański imperializm i reprodukują jego podstawy. Jak piszą:

[...] biorąc pod uwagę fakt, że edukacja jest kluczowa dla wszystkich projektów hegemonicznych, budowanie globalnej hegemonii w sektorze szkolnictwa wyższego jest zdecydowanie wysoką stawką w tej grze (Marginson i Ordorika 2011: 89). 
Tego rodzaju hegemonia realizowana jest w ramach i poprzez instytucje, w tym formy instytucjonalne, na których opiera się szkolnictwo wyższe. Hegemoniczne stosunki władzy w globalnym szkolnictwie wyższym kształtowane są zatem $\mathrm{w}$ trzech domenach wyodrębnionych przez Stevena Lukesa (2005). Pierwszą jest instytucjonalny obszar centralności, siły i prestiżu. Jak piszą Marginson i Ordorika, w globalnym krajobrazie szkolnictwa wyższego istnieją instytucje i całe systemy, które poprzez łatwiejszy dostęp do środków finansowych, zakumulowane zasoby finansowe i kadrowe czy wreszcie kontakty z ośrodkami globalnej władzy dominują nad innymi. Drugą domeną hegemonii jest władza sprawowana w obrębie dyskusji dotyczących globalnej polityki czy kształtowania strategii politycznych. Trzecią domeną hegemonii są procesy kształtowania pola szkolnictwa wyższego i konstruowania dominujących w nim wartości, figur instytucjonalnych czy projektowania wzorcowych modelów reform (Marginson i Ordorika 2011: 79-111). Niezaprzeczalnym faktem jest to, że w globalnym krajobrazie szkolnictwa wyższego większość krajów jest raczej „ustawobiorcą” (policy-takers) niż „ustawodawcą” (policy-makers) (King 2009: 86). Hegemonia jeszcze wyraźniej widoczna jest w takich kwestiach, jak standaryzacja języka, stylów pisania czy centralizacja samych obszarów cyrkulacji wiedzy. Formami zinstytucjonalizowanej hegemonii w sektorze szkolnictwa wyższego, odpowiedzialnymi za proces zacierania granic między tym, co prywatne a tym, co publiczne w uniwersytetach publicznych są - jak wskazują Marginson i Ordorika - z jednej strony procesy powstawania państwa ewaluacyjnego i wdrażania powiązanych z nim reform w paradygmacie Nowego Zarządzania Publicznego, z drugiej zaś - wzorcowa forma współczesnego uniwersytetu badawczego, a więc publiczny uniwersytet przedsiębiorczy. Warto zaznaczyć, że nie sposób oddzielić hegemonii w szkolnictwie wyższym od tej sprawowanej przez kraje anglosaskie w globalnej sferze polityki i gospodarki, a najważniejsze procesy zachodzące $\mathrm{w}$ interesującym nas sektorze wiążą się ze znacznie głębszym kryzysem, który w układzie sił między klasami rozpoczął się wraz z narodzinami globalnej dominacji doktryny neoliberalnej.

\subsection{Neoliberalizm i globalizacja}

Choć rosnącą problematyczność rozróżnienia na to, co publiczne i to, co prywatne można sprowadzić do fundamentalnych sprzeczności wpisanych w sam program nowoczesności, to przyznać należy, że w ostatnim czasie hybrydyzacja porządków w realiach szkolnictwa wyższego stała się problemem odczuwalnym szczególnie dotkliwie. Zdają z tego sprawę choćby, przywoływani wcześniej badacze i badaczki współczesnych przemian systemu szkolnictwa wyższego. Jedno ze źródeł destabilizacji granicy przebiegającej między tym, co publiczne a tym, co prywatne tkwi 
w zmianach, jakie zachodzą w obrębie instytucji nowoczesnego państwa. Opierając się na opracowaniach poświęconych relacji między uniwersytetem a zmieniającym się sposobem działania administracji państwowej (Kwiek 2001; 2006; 2010; 2014; Powell i Hendricks 2009; Rhoads i Torres 2006; King 2007; Bleiklie 1999; Neave 1998; 2012; Marginson 1997), można przyjąć założenie, że to przede wszystkim przemiany i potrzeby skonfliktowanej sfery gospodarczej wyznaczają rytm zmian struktur państwowych, a zarazem determinują kształt wyzwań, z którymi musi się mierzyć współcześnie instytucja uniwersytetu. Można zatem stwierdzić, że państwo, czy też będące jego przedłużeniem instytucje ponadnarodowe, pełnią dziś w znacznej mierze rolę służebną wobec potrzeb kapitalistycznej gospodarki (Harvey 2008) i w ramach projektowanych reform sektora publicznego sprzyjają procesom stopniowego podporządkowywania go interesom klas posiadających (Dumenil 2009: 25).

Najpowszechniejszym określeniem, które stosowane jest przy wyjaśnianiu istoty tych zmian, jest „neoliberalizm”, tj. „hegemoniczny projekt koncentracji władzy i bogactwa w rękach elit” (Saad-Filho i Johnston 2009: 14), który nie będąc określonym sposobem produkcji, wyznacza ramę ideologiczną dla działań zarówno w sferze polityki i gospodarki, jak kultury czy edukacji. Jak twierdzi David Harvey (2008), neoliberalizm jest narzędziem przywracania władzy klasowej kapitalistów. Początki jego długo przygotowywanego triumfu (Peck 2010; Mirowski 2013) sięgają okresu załamania powojennego „keynesowskiego kompromisu”, odstępstwa od porozumień z Bretton Woods, i wiążą się z momentem wejścia zachodnich gospodarek w stan kryzysu. Symboliczną inaugurację okresu hegemonii neoliberalizmu stanowi przejęcie władzy w Wielkiej Brytanii przez rząd Margharet Thatcher w 1979 r. i objęcie prezydentury w USA przez Ronalda Reagana rok później.

Neoliberalizm jest kategorią powszechnie używaną zarówno w dyskursie nauk społecznych, jak i w prasowej publicystyce. Nie jest ona jednak wolna od wieloznaczności. Terry Flew (2014) wyróżnił sześć sposobów wykorzystywania pojęcia „neoliberalizm” w naukach społecznych i analizach dotyczących ostatnich przekształceń sfery społeczno-gospodarczej. Po pierwsze, pojęcie to, często w tonie moralnego oburzenia, stosuje się w krytyce dzisiejszych przemian. Po drugie, stanowi ono kategorię deskryptywną, dotyczącą tego, ,jak się dziś rzeczy mają” na styku państwa i kapitalistycznej gospodarki. Po trzecie, określa ramę instytucjonalną lokalnej postaci kapitalizmu. Po czwarte, służy jako pojęcie oddające istotę „dominującej ideologii globalnego kapitalizmu" (Harvey 2008; Saad-Filho i Johnston 2009). Po piąte, w ujęciu Foucaulta i Gramsciego jest pewnym sposobem urządzania oraz formą hegemonii (Olssen i Peters 2005). Po szóste, za jego pomocą można wyróżnić pewien wariant teorii i dyskursu ustawodawczego w szerokiej ramie liberalizmu (Flew 2014). Powyższa lista nie wyczerpuje z pewnością znaczeń pojęcia „neoliberalizm”, pozwala jednak naświetlić podjęte w tym artykule decyzje analityczne. 
Pamiętając o różnych znaczeniach przypisywanych tej kategorii w naukach społecznych, będziemy rozumieć neoliberalizm jako ogólną ideologiczną ramę wyznaczającą współrzędne i kierunek przemian w relacjach między kapitalistycznym państwem a szkolnictwem wyższym. Posłużymy się wobec tego teoriami, których autorzy, jak stwierdza Flew (2014: 56), wyszli z analitycznie najsilniejszą dotąd definicją neoliberalizmu, czyli teoriami marksistowskimi (Smith 2006). Neoliberalizm widziany oczami marksistów jest przed wszystkim „teorią praktyk polityczno-ekonomicznych, która głosi, że ludzkiemu dobrobytowi najlepiej służyć będzie uwolnienie przedsiębiorczości w ramach instytucjonalnych, których cechy charakterystyczne to: mocne prawo własności prywatnej, wolne rynki i wolny handel" (Harvey 2008: 9, 90). Jednym z głównych założeń neoliberalizmu jest zatem nie tylko przekonanie o tym, że praca jest sprzedawana na rynkach za swoją wartość (w ten sposób dochodzi do przesłonienia i wyparcia jakichkolwiek znamion antagonistycznego charakteru stosunków produkcji), ale również przekonanie, że to rynki są najefektywniejszym i optymalnym mechanizmem, za pomocą którego można nie tylko zorganizować rzeczywistość gospodarczą, ale również każdą inną sferę życia społecznego.

Szczególne funkcje w marksistowskich analizach neoliberalizmu przypisuje się, wbrew oficjalnej doktrynie neoliberałów, instytucji państwa i jego agendom (Wacquant 2012). To pierwsze w tym ujęciu rozumiane jest jako aparat, „którego zasadniczą misją będzie ułatwianie zyskownej akumulacji kapitałowi krajowemu i zagranicznemu" (Harvey 2008: 16). W podobny sposób można rozumieć współczesną funkcję państwa w stosunku do sektora szkolnictwa wyższego. Instytucje sektora publicznego uznaje się natomiast, z jednej strony, za obszar „konstruowania przyzwolenia" (Harvey 2008: 54-90) na neoliberalny kapitalizm, to znaczy za instytucje, które wciąż pełnią kluczową funkcję „aparatów ideologicznych państwa” (Althusser 2000). Z drugiej zaś strony traktuje się je jako przestrzeń lokalizacji kolejnych rynków, przekształcaną w sposób umożliwiający najswobodniejsze pomnażanie wartości przez kapitał. Mitem okazuje się więc neoliberalny dogmat minimalnego państwa sprowadzonego do roli stróża nocnego, a „pod ideologicznym płaszczykiem nieingerowania państwa w gospodarkę [neoliberalizm - K. Sz.] dokonuje szeroko zakrojonych i drastycznych ingerencji we wszystkie obszary życia społecznego" (Saad-Filho i Johnston 2009: 19). Jak twierdzi Ronaldo Munck (2009: 104), ,interwencje rządu odgrywają decydująca rolę w tworzeniu rynków”, nie omijając przy tym oczywiście sfery nauki i szkolnictwa wyższego. Istotą doktryny neoliberalnej jest bowiem pragnienie, aby „poddać każdy aspekt życia społecznego logice rynku i przekształcić wszystko w towar, który może być posiadany oraz kupowany i sprzedawany dla zysku" (Callinicos 2006: 6).

Na poziomie globalnym i transnarodowym możemy zidentyfikować neoliberalne hegemoniczne dyskursy polityczne dotyczące gospodarki wiedzy, szkolnictwa 
wyższego i ich wzajemnych relacji. Stanowią one albo efekt rozważań nad pionierskimi przedsięwzięciami reform w krajach kapitalistycznego centrum (Stany Zjednoczone, Wielka Brytania, Australia, Francja, Holandia) (Neave 2012), albo punkt wyjścia do reformowania systemów szkolnictwa wyższego w krajach półperyferyjnych i peryferyjnych. Uwzględnienie ich w analizie umożliwi nam zrozumienie zmian, jakie poprzez translacje tych dyskursów dokonały lub dokonują się na poziomie systemów i gospodarek narodowych.

W obliczu rozwoju projektu neoliberalnego mamy w ostatnich dekadach do czynienia z coraz intensywniejszym poszerzaniem zakresu funkcji szkolnictwa wyższego. Na każdym z poziomów: globalnym (OECD), transnarodowym/ponadnarodowym (np. Komisja Europejska; KE 2006; 2011) i krajowym/lokalnym podkreśla się, że uniwersytet publiczny zajmuje jedno z naważniejszych miejsc w budowie i rozwoju kapitalistycznych gospodarek opartych na wiedzy. Wraz z tym zainteresowaniem zmieniają się relacje, w jakie uwikłane są uniwersytet, gospodarka i państwo, a renegocjacji poddany zostaje tradycyjny kontrakt, zawarty w czasach dominacji zachodniego modelu państwa dobrobytu między państwem a instytucjami szkolnictwa wyższego (Kwiek 2005). W polityce realizowanej wobec uniwersytetów przez państwa Zachodu od lat 80., a więc od początku rządów neoliberałów, następuje przejście od bezpośredniej kontroli państwowej nad systemami szkolnictwa wyższego do kontroli państwowej sprawowanej za pośrednictwem mechanizmów rynkowych i rynkopodobnych (Paradeise, Reale, Bleiklie i Ferlie 2009; Paradeise, Reale i Goastellec 2009; McLaughlin, Osborne i Ferlie 2002; Antonowicz 2004). Mamy tu do czynienia z dwoma trendami - z jednej strony z coraz większą presją na wzmacnianie autonomii instytucji szkolnictwa wyższego (autonomii rozumianej przede wszystkim jako swoboda prowadzenia działań przedsiębiorczych), z drugiej strony - w ramach nieustających reform z projektowaniem roli uniwersytetów jako instrumentów realizacji krajowych polityk (rozumianych najczęściej jako sprzyjanie wzrostowi gospodarczemu; Gornitzka i Maassen 2007). Neoliberalna globalizacja stanowi najogólniejszą ramę dla analizowanych procesów.

\subsection{Globalizacja i szkolnictwo wyższe}

W ciągu kilkunastu lat, które minęły od czasu, gdy Simon Marginson i Garry Rhoades (2002) czy Sheila Slaughter (2001), podkreślali, że w badaniach nad szkolnictwem wyższym zbyt wielką wagę przykłada się do poziomu krajowego i narodowego, natomiast zbyt mało analiz poświęca się specyfice wpływów procesów powiązanych z globalizacją na dwa powyższe poziomy, wiele się zmieniło. Literatura dotycząca tego zagadnienia (King, Marginson i Naidoo 2011; 2013), skupiona jest zwłaszcza na takich problemach, jak: globalne rządzenie w szkolnictwie wyższym (King 2009), rola transnarodowych organizacji w regulowaniu pola szkolnictwa wyższego (van der Wende 2011), globalne rankingi uniwersytetów (Hazelkorn 
2008; 2011; Locke 2013; Lo 2014) czy kwestia transnarodowego kapitalizmu akademickiego (Cantwell i Kauppinen 2014). W innych analizach akcent jest położony głównie na to, w jaki sposób konkretne instytucje szkolnictwa wyższego radzą sobie z różnymi wyzwaniami globalizacji (Münch 2014). Wydawać by się zatem mogło, że globalne pole szkolnictwa wyższego jest dzisiaj w badaniach głównego nurtu dobrze rozpoznane.

Jak pisze jednak Peter Scott, choć nie wszystkie uniwersytety podejmują aktywności na skalę międzynarodową czy globalną, wszystkie poddane są presji ze strony procesów związanych z globalizacją i głównych aktorów działających w ich ramach (Scott 1998: 122; Marginson i van der Wende 2009: 26).W toku formowania się globalnego obszaru szkolnictwa wyższego relacje zawiązywane pomiędzy jego indywidualnymi, lokalnymi i krajowymi składnikami pogłębiają się, a procesy zachodzące z ich udziałem ulegają znaczącemu przyspieszeniu. Odnosi się to zarówno do rzeczywistości przeżywanej przez instytucje będące aktywnymi graczami umiędzynarodowienia, jak i tej będącej udziałem instytucji poddanych jedynie presjom związanym z globalizacją. Pomimo tego, że socjologowie, politologowie czy filozofowie wyróżniają wiele społecznych form globalizacji, badacze głównego nurtu usiłują zachować ostrożność przy otwartym deklarowaniu własnych stanowisk czy sposobów ujmowania tych procesów. Przykładu takiej praktyki dostarczają Simon Marginson i Marijk van der Wende, starający się analizować zjawisko globalizacji w oderwaniu od „ideologicznego bagażu”, traktując ją jako „geoprzestrzenny proces rosnącej współzależności i konwergencji, w którym wzmocnieniu ulegają światowe i ponadregionalne obszary" (Marginson i van der Wende 2009: 19). W takim ujęciu szkolnictwo wyższe odgrywa istotną rolę $\mathrm{w}$ wielu procesach powiązanych z globalizacją, a piętno odciskają na nim nie tylko jej gospodarcze aspekty, ale również te dotyczące zmian związanych z kulturą i mobilnością siły roboczej (Sassen 2007). Globalizacja czy szerzej: wytwarzanie globalnego reżimu szkolnictwa wyższego nie powinno być oczywiście traktowane jako zjawisko o uniwersalnym oddziaływaniu, coś na kształt homogenicznego pasa transmisyjnego określonych hegemonicznych treści. Procesy te wywierają zróżnicowany wpływ, zależny od instytucji, której się przyjrzymy, krajowego kontekstu czy akademickiej tradycji, w ramach której dana instytucja funkcjonuje. Trudno jednak nie zauważyć, że krajowe systemy w ostatnim czasie coraz bardziej się do siebie upodabniają. Przywołani wyżej Marginson i van der Wende wyróżniają trzy rodzaje globalnych transformacji w szkolnictwie wyższym. Pierwszym z nich są globalne przekształcenia o charakterze „integracjonistycznym", to znaczy takie sposoby spajania systemów szkolnictwa wyższego, które zarówno odróżniają się od krajowych procesów, jak i nie dają się na tym poziomie kontrolować, zatrzymać czy uniknąć (Marginson i van der Wende 2009: 24). Tego typu zjawiska to np. globalna integracja i koncentracja najbardziej prestiżowego obiegu naukowego czy globalna mobilność najlepiej wykwalifikowanej kadry, przyjmująca często formę „drenażu mózgów”. Drugim rodzajem przekształceń 
są globalne transformacje „krajowo-konwergencyjne”, promujące określone zestawy wartości i technologii społecznych, a skutkujące wytworzeniem „wzorca wspólnych zmian w krajowych systemach szkolnictwa wyższego, prowadząc tym samym do ich konwergencji i integracji” (Marginson i van der Wende 2009: 24). Wśród procesów o takim charakterze można wskazać choćby współczesne upowszechnianie się języka angielskiego jako globalnego języka wymiany naukowej czy coraz bardziej zbliżone do siebie krajowe modele kształcenia na poziomie doktoranckim. Trzecim trendem są zmiany krajowe o charakterze równoległym do transformacji globalnych, przez co należy rozumieć np. krajową translację modelu reform z paradygmatu Nowego Zarządzania Publicznego w sektorze szkolnictwa wyższego. Procesom tym towarzyszy tendencja do stopniowego „wykorzeniania” niektórych instytucji szkolnictwa wyższego z krajowych ram rządzenia (Marginson, van der Wende 2009), przejawiająca się m.in. w obszarach finansowania pochodzącego z czesnego opłacanego przez zagranicznych studentów (najwyraźniej tę tendencję widać w systemach krajów anglosaskich), w finansowaniu badań (w ramach dużych regionalnych programów finansowania badań, jak np. w Unii Europejskiej) czy w ponadgranicznym kształceniu podlegającym decyzjom zapadającym na poziomie międzynarodowym.

Aby jak najlepiej przedstawić zachodzące obecnie procesy odpowiedzialne za porządkowanie globalnego poziomu szkolnictwa wyższego, należałoby wskazać na dwie, pozornie przeciwstawne tendencje. $Z$ jednej strony byłaby to postępująca standaryzacja, z drugiej zaś - coraz większe różnicowanie się i hierarchizowanie zarówno globalnego pola jako takiego, jak również wewnętrznej struktury krajowych systemów szkolnictwa wyższego (Marginson 2011: 409-410). Są to procesy analogiczne do dyskutowanej często w odniesieniu do postfordyzmu, postmodernizmu czy późnej nowoczesności dialektyki homogenizacji i heterogenizacji. David Harvey (1990) postrzega ją jako następstwo kompresji czasoprzestrzennej. Obie te tendencje zbiegają się w tym, co Roger King określa mianem regulacji. Jak pisze w swojej książce Governing Universities Globally:

Regulacja [...] posiada rozległe źródła i tryby, a obejmuje swoim działaniem zarówno prywatne, jak i publiczne instytucje. Składa się z procesów zamierzonej standaryzacji, internalizacji norm, hierarchii $\mathrm{w}$ dowodzeniu polem oraz wprowadzania rynków jako rozwiązań dla problemów powiązanych z koordynacją i zbiorowym działaniem (King 2009: 1).

Mechanizmy te działają na czterech poziomach: 1) międzyrządowym, 2) transrządowym, tj. obejmującym działania odpowiednich ministerstw z różnych krajów, 3) ponadnarodowym, czyli w obszarze funkcjonowania instytucji międzynarodowych, 4) transnarodowym, a więc koordynowanym przez niepaństwowych aktorów instytucjonalnych (King 2009). Krajowy system szkolnictwa wyższego, jak również 
pojedyncze instytucje mogą zostać poddane wpływom procesów zachodzących na którymkolwiek z tych poziomów, jak również na wszystkich jednocześnie.

W regulowanym i rządzonym z poziomu globalnego szkolnictwie wyższym funkcjonują trzy wzorce, które replikowane są na poziomie krajowym (King 2009). Pierwszym z nich jest promowane od lat przez Bank Światowy (2002) przekonanie, że uniwersytety i szerzej: systemy szkolnictwa wyższego jako siły napędowe gospodarek opartych na wiedzy stanowią kluczową instytucję dla rozwoju ekonomicznego. Drugim jest dążenie do wewnętrznego różnicowania krajowych systemów szkolnictwa wyższego. Trzecim, być może najważniejszym, wzorcem jest zestaw reform dokonywanych wedłud zasad Nowego Zarządzania Publicznego, to znaczy zastosowanie do regulacji publicznego sektora mechanizmów pochodzących przede wszystkim z sektora prywatnego. Marginson i van der Wende (2007) uważają, że w ostatnich dwóch dekadach to właśnie te reformy były najsilniejszym pojedynczym czynnikiem zmiany w publicznym szkolnictwie wyższym. Dla Kinga jest to jeden z nielicznych zalegitymizowanych i zinstytucjonalizowanych globalnie modeli rządzenia dla szkolnictwa wyższego, $w$ dodatku taki, który „dostarcza normatywnego systemu znaczeń, który legitymizuje upadek akademickich i kolegialnych form władzy na uniwersytetach na rzecz tej sprawowanej przez wspieranych przez państwo menadżerów" (King 2009: 58). Powyższe wzorce mają potężny, choć nie bezwarunkowy wpływ na krajowe rozwiązania z zakresu polityki szkolnictwa wyższego.

Choć, historycznie rzecz biorąc, najczęściej mieliśmy do czynienia raczej z krajowymi postaciami izomorfizmu instytucjonalnego, to dzisiaj, przy dużym udziale takich ciał, jak OECD czy Komisja Europejska, stopniowo dokonuje się światowa konwergencja polityk (Martens i Weymann 2007), a „największy wpływ na różne formy ujednolicania i regulowania sektora ma rozpowszechnienie się i idące za tym oddziaływanie globalnych standardów i globalnych punktów odniesienia" (King 2009: 3). Pod nieobecność globalnego suwerennego bytu czy też globalnego państwa (Marginson 2011a) regulacja i rządzenie systemami szkolnictwa wyższego z tego poziomu odbywa się głównie poprzez sieci, kierowanie na odległość, upowszechnianie ekspertyz i podobne działania globalnej merytokracji. Monopol rządowy na regulację obszaru szkolnictwa wyższego został obecnie w wielu krajach na świecie albo przełamany, albo przynajmniej mocno podważony.

Sukces na tym polu w ostatnich dekadach odniosły za to organizacje międzynarodowe (King 2009: 118). Globalne standardy „formułowane są dziś raczej przez międzyrządowe, jak również prywatne ciała” (King 2009: 100). To, co robi np. OECD, można określić mianem „rządzenia za pośrednictwem porównań” (Martens 2007), co oznacza koordynowanie zmian w szkolnictwie wyższym poprzez rozbudowane procesy kształtowania dyskursów i tworzenie benchmarków. Tego rodzaju instytucje, nazywane przez Kinga (2009: 92) „standaryzatorami” , tworzą wskaźniki i na ich podstawie przeprowadzają oceny krajowych systemów szkolnic- 
twa wyższego (King 2009: 123). Dzięki temu zdolne są do formułowania kodeksów „najlepszych praktyk”, które następnie z mniejszą lub większą skutecznością wdrażane są na poziomie regionalnym przez metaorganizacje (2009: 89) zajmujące się promowaniem ustanowionych standardów lub na poziomie krajowym przez ministerstwa krajów członkowskich zrzeszonych w OECD. Oczywiście, mamy tu do czynienia z różnicami zachodzącymi między ogólną akceptacją pewnych wzorców globalnych, a ich wdrożeniem na poziomie krajowym i lokalnym. Choć wszystkie instytucje szkolnictwa wyższego w mniejszym lub większym stopniu poddane są oddziaływaniu sił globalnych, to wszystkie obciążone są również lokalnymi tradycjami i poddane specyficznie krajowym regulacjom.

Istotną funkcję w globalnej regulacji instytucji uniwersytetu pełnią obecnie globalne rankingi uniwersytetów (Hazelkorn 2008; por. krytyczne ujęcie: Szadkowski 2015). Warto jednak odnotować za Kingiem, że:

[...] globalne i krajowe rankingi uniwersytetów starają się sprawić by świat szkolnictwa wyższego w większym stopniu dawał się poznać, by był bardziej uporządkowany na wzór konkurencyjnych rynków oraz by w coraz większym stopniu podlegał wzorcowi rządzenia właściwemu urynkowionej, konkurencyjnej oraz coraz bardziej transnarodowej organizacji (King 2009: 162).

Kluczem do uzyskania wysokiej pozycji w rankingach są, mierzone konkretnymi wskaźnikami, osiągnięcia badawcze. Wydawać by się mogło więc, że mamy do czynienia z kryterium wewnętrznym względem pola naukowego. Simon Marginson (2004) uważa jednak, że konkurencja o status, czyli proces, w który wpisują się krajowe i globalne rankingi, jest w szkolnictwie wyższym znacznie bardziej powszechna, a także znacznie bardziej niebezpieczna dla publicznych interesów niż konkurencja rynkowa w sensie ekonomicznym. Pościg za statusem określanym w ramach globalnych porównań jest również jednym z istotnych elementów składających się na proces globalnego izomorfizmu instytucjonalnego.

Nawet jeśli uniwersytety w coraz większym stopniu biorą udział w globalnej konkurencji, to wciąż walczą przede wszystkim o regionalne, krajowe i lokalne finansowanie ze środków publicznych i prywatnych. Zatem mimo postępującej regulacji z poziomu globalnego nie doszło do całkowitego wypchnięcia państwa narodowego poza globalny obraz szkolnictwa wyższego. Co więcej, to państwa narodowe wciąż w głównej mierze finansują i regulują ten sektor. Nikt raczej nie traktuje poważnie postulatów likwidacji publicznego krajowego finansowania uniwersytetów. Powszechnie uważa się, że tylko ono może być środkiem podtrzymywania zdolności do - konkurencyjnej w skali globalnej - naukowej innowacji. Nawet wielki biznes i transnarodowy kapitał nie mają nic przeciwko szczodremu finansowaniu nauki ze środków publicznych, o ile mogą ustawić się na końcu łańcucha finansowania i bez przeszkód korzystać z wypracowanych przez krajowe instytucje naukowe wytworów. Nie zamierzają się jednak w żaden nieprzymuszony sposób do tego dokładać. 


\section{Hybrydyzacja tego, co publiczne i tego, co prywatne na poziomie krajowym}

W dalszej części będziemy się zajmować procesami, dzięki którym zmienia się współczesne państwo, a wraz z nim relacje instytucji państwowych i elementów sektora publicznego oraz rozumienie odpowiedzialności za dobro publiczne. Jest to niezwykle szerokie zagadnienie, w związku z czym skoncentrujemy się na jednym z przejawów tych zmian, tj. na przekształceniach dokonujących się w paradygmacie Nowego Zarządzania Publicznego. Jak już wspomniano, powszechnie uważa się, że to właśnie te procesy w decydujący sposób wpłynęły na kształt zmian w obrębie sektora szkolnictwa wyższego w krajach anglosaskich, wobec czego stanowią obecnie promowany w skali globalnej wzorzec regulacji publicznego szkolnictwa wyższego. Marginson i van der Wende (2009: 21) piszą, że translacja reform w paradygmacie Nowego Zarządzania Publicznego „podlega kontroli na poziomie krajowym i przez to jest zniuansowana [...]. Kraje selektywnie wykorzystują wzorce reform w paradygmacie Nowego Zarządzania Publicznego, filtrując je przez własną historię i właściwe sobie mechanizmy”. Mimo to sam wzór czy swoisty „typ idealny” tych reform stanowi dobry punkt wyjścia do zrozumienia procesów zachodzących obecnie w krajowych systemach szkolnictwa wyższego. Przyjrzymy się wobec tego jednemu z najważniejszych aspektów tych reform. Przeprowadzimy zatem analizę sposobów, $\mathrm{w}$ jakie ustanawia się procedury ewaluacji i kryteria pomiaru efektywności pracy oraz dokonań w ramach sektora. To na ich podstawie bowiem, w sposób konkurencyjny czy też quasi-rynkowy, rozdzielane są dzisiaj publiczne finanse, zarówno na kształcenie, jak i na badania naukowe. Procesy te są jednym z najważniejszych przejawów dostrzeganej przez badaczy szkolnictwa wyższego hybrydyzacji porządków tego, co prywatne i tego, co publiczne. To one również umożliwiają nadbudowanie się koordynacyjnych mechanizmów rynkowych i pozwalają na uchwycenie istoty krajowych procesów stymulujących dalszą hybrydyzację w obrębie sektora.

\subsection{Państwo ewaluacyjne i reformy w paradygmacie Nowego Zarządzania Publicznego}

W celu wskazania źródła najważniejszych przekształceń, jakie miały miejsce na poziomie zachodnich systemów szkolnictwa wyższego, należy cofnąć się nieco w przeszłość. Lata 80. XX wieku były dla szkolnictwa wyższego w Europie Zachodniej okresem burzliwych zmian, kryzysu, ale jednocześnie znaczącego przełomu (Neave i van Vought 1991). Doszło wówczas do szeroko zakrojonych zmian w relacjach między państwem a sektorem szkolnictwa wyższego (Neave i van Vought 1994), na czele ze zmianą „społecznego kontraktu między państwem a uniwersytetem” (Kwiek 
2005: 324-328), ale również z neoliberalnymi przekształceniami samej instytucji państwa i sposobu jego funkcjonowania (Harvey 2008). Innymi słowy, doszło do przejścia od koncepcji „dużego państwa” do państwa silnego i skutecznego (Toonen 2007: 42), od państwa dyscypliny do państwa kontroli i nadzoru. Marginson (1997b) pisze o modelu państwa sterującego sektorem publicznym na odległość, zaś King (2009) używa określenia „państwo regulacyjne”. Innym jeszcze sformułowaniem, które oddaje istotę współczesnych przemian, jest „państwo ewaluacyjne”; terminem tym będziemy się posługiwać w dalszej części tekstu.

Za bezpośrednią przyczynę powstania państwa ewaluacyjnego uważa się kryzys, jakiego w latach 80. XX wieku na Zachodzie doświadczyła sfera wydatków publicznych. Był to rezultat wdrażania polityki neoliberalnej. W przypadku sektora szkolnictwa wyższego istotne znaczenie miał również dokonujący się równolegle proces umasowienia dostępu. W konsekwencji przekształceń sektora publicznego zmieniły się postulaty formułowane pod adresem uniwersytetu. W nowych warunkach miał on stać się narzędziem realizacji zadań przede wszystkim gospodarczych, nie zaś - jak to było wcześniej - społecznej misji.

Wyzwania związane z wkraczaniem większości gospodarek Zachodu w okres późnego kapitalizmu czy stadium gospodarki opartej na wiedzy wymagały powołania nowych instytucji sprawujących władzę nad systemami szkolnictwa wyższego. Konieczne było również wypracowanie takich mechanizmów zarządzania, które byłyby bardziej efektywne i elastyczne niż dotychczasowe formy ścisłej kontroli biurokratycznej. Chociaż różne formy ewaluacji od zawsze były częścią sprawowania władzy i ustawodawstwa, to wraz z przejściem do realizacji modelu państwa ewaluacyjnego zmieniła się zarówno jej postać, jak i cele (Neave 1998: 273). Za Guyem Neavem (2012: 15) można wskazać trzy główne problemy systemowe, które nowy model państwa ewaluacyjnego miał rozwiązać. Po pierwsze, należało zastąpić stare mechanizmy administracyjne stosowane w obrębie sektora takimi, które będą łatwiej przystosowywać się do sytuacji rosnącego wpływu na system szkolnictwa wyższego czynników zewnętrznych, przede wszystkim rynkowych. Po drugie, sektor miał zostać objęty kontrolą pozwalającą na wypracowanie kryteriów i procedur, które pozwoliłyby na jego nieustanny monitoring i bieżące diagnozowanie zachodzących w nim procesów. Po trzecie, chodziło o przyspieszenie działania administracji i umożliwienie interwencji o bardziej zindywidualizowanym charakterze, lepiej odpowiadających na potrzeby i problemy konkretnych instytucji.

Najogólniej rzecz ujmując, zmiany te doprowadziły do zwiększenia swobody podejmowania decyzji przez władze poszczególnych instytucji szkolnictwa wyższego. Założenie władz publicznych w tym kontekście jest stosunkowo proste: im skuteczniejsze, bardziej pewne (oparte na kryterium ilościowym) i szybciej reagujące są mechanizmy kontroli, tym na więcej można pozwolić instytucjom funkcjonującym w danym sektorze. W związku z tym w obrębie dyskursów reformatorskich dokonało się przejście od pojmowania kwestii uniwersyteckiej autonomii w kategoriach 
jednostkowej i indywidualnej wolności akademickiej do autonomii rozumianej wyłącznie w kategoriach swobodnego działania instytucji. Wraz ze wzrostem znaczenia zewnętrznych procesów oceny pojedynczych instytucji zmalała też ranga procedur typu peer-review (Neave 1998: 277-278).

W kontekście rozwoju praktyk ewaluacji w sektorze szkolnictwa wyższego Neave pisze o rosnącym poziomie „skomplikowania statystycznego” (Neave 2012: 21) tych procesów. Oznacza to wprowadzenie na linii państwo - sektor szkolnictwa wyższego/instytucje szkolnictwa wyższego wielu skomplikowanych miar określających zarówno dynamikę kształtowania się populacji włączonej w sektor, jak i poziomy produktywności naukowej kadry akademickiej czy też liczby wypromowanych absolwentów. Zjawisku temu towarzyszy postępująca kontraktualizacja relacji między władzami publicznymi a uniwersytetami (przede wszystkim tych dotyczących publicznego finansowania instytucji akademickich). Monitoring dynamiki zmian w sektorze daje państwu większą możliwość poddawania tych kontraktów ciągłym negocjacjom. Nie są one zatem zawierane na dłuższy okres, lecz mają charakter warunkowy i cały czas pozostają otwarte na renegocjacje.

Ciągła ewaluacja przeprowadzana przez państwowe agencje nadzoru czy ciała pośredniczące (intermediary bodies) dokonująca się za pomocą różnorodnych audytów, wskaźników produktywności itd., dużo głębiej przenika instytucje szkolnictwa wyższego, niż czyniła to wcześniej kontrola biurokratyczna (Neave 1998: 266). Jednak kontrola nad sektorem ze strony państwa nie kończy się na tego rodzaju praktykach. Jak pisze Neave (1998: 281), „państwo ewaluacyjne kieruje również poprzez bezpośrednie oddziaływanie na owe ciała pośredniczące lub dostosowując sam poziom sprawowanej przez nie odpowiedzialności, w niektórych przypadkach zaś przez niszczenie czy tworzenie agencji nadzoru”. Okazuje się więc, że państwo ewaluacyjne wcale nie jest mniej natarczywe niż dawna biurokracja. Co więcej, dzięki operowaniu różnorodnymi wskaźnikami ilościowymi ma możliwość objęcia kontrolą sfer niedostępnych dla tradycyjnej biurokracji.

Pojawienie się na horyzoncie europejskiego szkolnictwa wyższego form aktywności wykraczających poza standardowe kształcenie i badanie, jak również uformowanie się państwa ewaluacyjnego było i jest ściśle powiązane z reformami realizowanymi w obrębie tego sektora według zasad Nowego Zarządzania Publicznego. Początkowo wprowadzano je w takich krajach, jak Wielka Brytania, Francja czy Holandia, obecnie również wdraża się je w krajach peryferyjnych, takich jak Polska (Czarnecki 2013). Neave uważa, że „reformy w paradygmacie Nowego Zarządzania Publicznego funkcjonują jako podzbiór - środki operacjonalizacji - państwa ewaluacyjnego" (Neave 2012: 22). Ich głównymi celami było podniesienie efektywności publicznych instytucji szkolnictwa wyższego oraz rozciągnięcie i utrzymanie publicznej kontroli nad coraz bardziej autonomizującymi się uniwersytetami. Tego rodzaju kontrola nie jest już jednak sprawowana w sposób bezpośredni czy scentralizowany, lecz realizuje się za sprawą bardziej subtelnych mechanizmów otwartej 
koordynacji. Ewan Ferlie i jego współpracownicy (2008) opisują kilka konsekwencji reform przeprowadzonych w paradygmacie Nowego Zarządzania Publicznego. Najważniejsze wśród nich jest stworzenie w obrębie sektora rynków czy quasi-rynków (Teixeira, Jongbloed, Dill i Amaral 2004; Jongbloed 2003) poprzez stymulowanie ogólnokrajowej konkurencji między instytucjami czy badaczami o zasoby (pochodzącymi zarówno ze źródeł prywatnych, jak i publicznych). Rola państwa i władzy publicznej sprowadza się w tym kontekście do „rozwijania wąskiego rynku szkolnictwa wyższego; akcent strategiczny położony jest raczej na różnorodność i wybór niż integrację i planowanie" (Ferlie, Musselin i Andresani 2008: 335). Pojawia się również dążenie do ustanowienia lub rozwinięcia systemu cen rynkowych za kształcenie i badanie, które umożliwiają lub umacniają produkcję opartą na formie towarowej oraz wymianę na zasadzie rynkowej. Rezultatem jest choćby dążenie do wprowadzenia lub zwiększenia czesnego za studia bądź ustanowienie różnych opłat za usługi świadczone przez uniwersytety publiczne na rzecz studentów. Ma to na celu rozwijanie i sprzyjanie kształtowaniu zachowań rynkowych wśród klientów instytucji. W obrębie sektora dochodzi też do ustanowienia i zaostrzenia podziału pracy między instytucjami publicznymi. Następuje wobec tego „koncentracja funduszy w instytucjach szkolnictwa wyższego o najlepszych wynikach" (Ferlie i in. 2008: 338), zaś „opuszczanie rynku przez usługodawców publicznych, którzy poniosą porażkę, jest akceptowane" (Ferlie i in. 2008: 337). Porażka w tej sytuacji jest rozumiana przede wszystkim jako niedopasowanie do zasad konkurencji rynkowej i przejawia się po prostu bankructwem lub wysokim poziomem zadłużenia.

Nie można jednak mówić o jednym, reprodukowanym w różnych krajach modelu reform w paradygmacie Nowego Zarządzania Publicznego, w ten sposób bowiem zatarłoby się lokalną specyfikę ich realizacji (Naschold 1996; Hood 1996). Jak słusznie wskazują Ferlie i współpracownicy (2008), kiedy przechodzimy od analizy modeli do analizy rzeczywistych systemów szkolnictwa wyższego, okazuje się, że zaprezentowane przez autorów narracje mieszają się i występują w stadiach hybrydalnych, będąc wypadkową licznych kompromisów między samymi narracjami, jak również efektem zastanych warunków lokalnych (path dependency - zależność od ścieżki; Krücken 2003).

Wszystkie te zmiany redefiniują stosunki władzy w instytucjach szkolnictwa wyższego na korzyść kierownictwa czy odpowiednich ministerstw zajmujących się alokacją budżetów i odpowiedzialnych za ustalanie warunków zatrudnienia na uczelniach. Tworzą też nowe podziały i napięcia między kadrą akademicką a kierownictwem poszczególnych instytucji, jak również między samymi pracownikami. Stosunek między uniwersytetem publicznym i jego administracją a zatrudnianą w jego ramach siłą roboczą staje się $\mathrm{w}$ wielu aspektach coraz bardziej podobny, choć nie identyczny, do stosunku między kapitałem a pracą. Jednym z jego wyrazów jest nie tyle forma pracy najemnej, ustanawiana w ramach relacji między władzami uniwersytetu a kadrą akademicką, ile mechanizmy kontroli i pomiaru efektywności pracy. 


\subsection{Kultura audytu i performatywność}

Opisując proces rozszerzania zakresu ewaluacji sektora publicznego, stanowiącego konsekwencję postępującej neoliberalnej dominacji klasowej nad społeczeństwem i gospodarką, którego częścią były reformy z klucza Nowego Zarządzania Publicznego, wielu autorów mówi o powstaniu „kultury audytu” (Shore i Wright 1999, 2015b; Strathern 2000) czy wręcz „społeczeństwa audytu” (Power 1997; Shore i Wright 2004). Jak zauważają badacze i badaczki tej problematyki, różnego rodzaju procedury oceny czy mierzenia efektywności pracy lub efektywności instytucjonalnej, wypracowane w sektorze prywatnym kapitalistycznych gospodarek, rozlały się po sektorze publicznym. W sektorze szkolnictwa wyższego doprowadziło to do przekształcenia uniwersytetu we wspólnotę audytowanych (Kruszelnicki 2010). „Kultura audytu” to sformułowanie określające sytuację, w której „zasady, techniki oraz uzasadnienia finansowej księgowości stały się głównymi zasadami organizacyjnymi we wszystkich aspektach społeczeństwa" (Shore i Wright 2015a). Wraz z jej pojawieniem się w szkolnictwie wyższym warunkiem publicznego finansowania publicznego szkolnictwa wyższego stała się nieustanna ścisła kontrola efektów pracy tego sektora. Skuteczne zestandaryzowane systemy ewaluacji pracy naukowej i dydaktycznej całych instytucji oraz poszczególnych pracowników miały dostarczać informacji o produktywności i wydajności, te zaś miałyby służyć podnoszeniu jakości instytucji i pracy zatrudnionych w nich naukowców. „Doskonałość” w badaniach czy kształceniu w obrębie „kultury audytu” ściśle łączy się z przejrzystością, wskaźnikami skuteczności, rozliczalnością i staje się częścią szerszego podejścia do sektora publicznego, który można podsumować jako value for money, oznaczający wymóg otrzymywania wartościowych usług za wnoszone do sektora publiczne pieniądze (Power 1997; Wright i Shore 2004).

Jak twierdzi Michael Power (1994), przyczyną eksplozji audytu były przekształcenia w sposobach pojmowania procesów administracji i organizacji, które „zdemontowały podzial na to, co prywatne i to, co publiczne" (1997: 10). Dla Shore'a i Wright (1999: 558) proces „audytowania” stanowi jedną z technologii politycznych w szkolnictwie wyższym i wiąże się z wprowadzaniem nowych stosunków władzy w obrębie sektora. Audyt przyczynił się do przekształcenia sposobu, w jaki ludzie z tego sektora odnoszą się do swojej pracy, władzy i współpracowników, ale przede wszystkim do samych siebie (Shore i Wright 1999: 561). Bycie podmiotem nieustannej oceny i porównań (zarówno na poziomie indywidualnym, jak i instytucjonalnym) dyscyplinuje, formatuje i ukierunkowuje na łatwo dające się przewidzieć przez administrację bądź instytucję władzy działania (Bruno 2011; Morrisay 2013).

Audyt ma charakter politycznej technologii (Shore i Wright 1999: 568; Ball 2003) dyscyplinującej pracę akademicką. Tworzy instytucjonalną kulturę uległości, przyczyniając się do przekształcenia tożsamości samego zawodu akademika. Ewalu- 
acja i porównania służą na współczesnych uniwersytetach do wytwarzania nowych podmiotów pracowniczych (Morrisay 2015), są przykładem neoliberalnych technologii politycznych umożliwiających zarządzanie w warunkach niepewności i regulowanie, nieprzewidywalnego z natury, obszaru, jakim jest kształcenie i nauka. Trzeba też pamiętać o powstawaniu antagonizmu między tymi, którzy oceniają, a ocenianymi oraz między kadrą zarządzającą instytucją czy krajowym systemem a pracownikami naukowymi i dydaktycznymi (Brenneis, Shore i Wright 2005: 7). Procedury ewaluacyjne są formą ponownej regulacji sektora szkolnictwa wyższego, a więc nie tyle „porzuceniem kontroli przez państwo, ile ustanowieniem nowej formy kontroli” (Ball 2003: 217). Wyrazem tego jest swego rodzaju „przymus wymierności” czy „tyrania liczb”, to znaczy „przymus redukowania złożonych społecznych czynności do prostych wyrażonych liczbowo punktów i klasyfikacji, by w ten sposób mogły być monitorowane, oceniane, przedstawiane i w sposób konkurencyjny hierarchizowane" (Brenneis, Shore i Wright 2005: 3). Miara jest narzędziem nieodłącznym zarówno od procesów neoliberalnego formatowania sektora publicznego, jak również od procesu rozciągania władzy i dominacji kapitału na nowych obszarach. Stanowi zatem narzędzie nie tylko politycznej, ale również ekonomicznej kontroli.

Problemy, jakich nastręcza kategoria miary, uchwycił kiedyś, z właściwą sobie błyskotliwością, Albert Einstein w często cytowanym stwierdzeniu, że „nie wszystko, co się liczy, daje się zmierzyć, nie wszystko, co daje się zmierzyć, się liczy”. W szkolnictwie wyższym zdominowanym przez neoliberalne technologie audytu niezdolność procedur (i wynikające z tego faktu niebezpieczeństwa) do uwzględniania całego spektrum aktywności akademickich wydają się dostrzegalne gołym okiem. To, co nie jest uwzględniane w ramach ewaluacji, przestaje być w ogóle widzialne i przestaje się liczyć dla funkcjonujących w ramach systemu podmiotów (Münch 2014: 73). Zwróćmy uwagę, że jednostki naukowe są dziś coraz częściej oceniane i porównywane niemal wyłącznie na podstawie osiągnięć badawczych, co prowadzi do coraz wyraźniejszego podziału pracy na uczelniach na dydaktykę i badania. Jedną z negatywnych konsekwencji tego stanu jest fakt, że napływający do systemu studenci, kształceni w większości przez pracowników specjalnie oddelegowanych do zadań dydaktycznych, mają dostęp do najnowszych wyników badań dopiero na późniejszych etapach kształcenia. Tendencja do standaryzowania oceny poprzez abstrakcyjną miarę ma również negatywne konsekwencje dla samego procesu rozwoju wiedzy i nauki. Jak pisze Richard Münch (2014: 75), „tam gdzie tendencja do standaryzowania jest szczególnie silna, wiedza będzie znajdować się w stanie stagnacji. Wszystko bowiem, co zaskakujące i odbiegające od powszechnie akceptowanej wiedzy, będzie odsiewane i wykluczane na gruncie metodologicznym”. Interesujące wydaje się też to, w jaki sposób i dlaczego scentralizowane procedury ewaluacji osiągnięć badawczych jednostek naukowych (szczególnie te promowane w ramach paradygmatu Nowego Zarządzania Publicznego), tworzą a następnie konsolidują i reprodukują różnice między instytucjami (Münch 2014: 68). 
Znaczenie miary i presji na wyniki jako form kontroli widoczne jest jeszcze na innej płaszczyźnie. Jean-François Lyotard już w 1979 r. w Kondycji ponowczesnej wskazywał, że wraz przejściem do gospodarki opartej na produkcji wiedzy kluczowego znaczenia nabiera „terror performatywności”. Stephen J. Ball zdefiniował to zjawisko w kontekście reform dokonanych w polu brytyjskiej edukacji, stwierdzając, że performatywność to:

technologia, kultura oraz sposób regulacji, które obejmują sądy, porównania oraz formy reprezentacji, będące środkami zachęty, kontroli, zużycia i zmiany - oparta jest ona na nagrodach i sankcjach (zarówno materialnych, jak i symbolicznych). Wyniki (performances) (pojedynczych podmiotów lub organizacji) służą za miary produktywności oraz wydajności czy reprezentacje „jakości” lub „momenty” promocji albo kontroli. Jako takie przedstawiają, zawierają czy reprezentują cenę, jakość czy wartość jednostki lub organizacji w polu oceny. Kwestia tego, kto kontroluje pole oceny, jest tutaj kluczowa (Ball 2003: 216).

Z tak rozumianą performatywnością wiąże się upowszechnienie konkurencji, zarówno na poziomie indywidualnym, jak i instytucjonalnym. Często jednak naiwnie zakłada się, że konkurencja w modelu performatywnym skutkuje całkowitym zastąpieniem organizacyjnej kooperacji oraz form współpracy (Ball 2003: 219). Jednak miara nadpisuje się raczej nad kolektywnymi formami produkcji w nauce i edukacji, których (o ile produkcja ma być skuteczna i dawać wyniki) nie sposób wyeliminować czy zastąpić. Wytworzone w ten sposób napięcie między kolektywną i kooperatywną podstawą naukowej produkcji a zindywidualizowaną i konkurencyjną miarą narzucaną w ramach reżimu performatywności można uznać za jedną ze sprzeczności powstających współcześnie w obrębie systemu szkolnictwa wyższego.

Ball zwraca jednak uwagę na jeszcze inne napięcie, wcześniej diagnozowane przez Lyotarda jako „prawo sprzeczności”. Performatywność zakłada bowiem zwiększenie intensywności i ogólne przyspieszenie najistotniejszych działań podejmowanych w obrębie systemu co wymaga coraz więcej energii, czasu i pieniędzy na rozrastające się wciąż procedury ewaluacyjne. $Z$ naszej perspektywy najważniejsza jest jednak sprzeczność między miarą i nieprzystającą do niej kolektywną rzeczywistością produkcji naukowej.

\section{Hybrydyzacja tego, co publiczne i tego, co prywatne na poziomie lokalnym/instytucjonalnym}

Instytucja uniwersytetu, w ramach której rozwijana jest od wieków nauka i prowadzone są procesy kształcenia, odznacza się specyfiką niedającą się zredukować ani do jednej z wielu części sektora publicznego, ani do zwykłego kapitalistycznego przedsięwzięcia realizowanego na rynkach. Z tego powodu wszystkie ingerencje 
i próby włączenia uniwersytetu w logikę któregokolwiek z tych porządków muszą skutkować licznymi kompromisami. Choć relacje łączące współczesne państwo narodowe i jego administrację z instytucjami sektora publicznego wydają się coraz luźniejsze i zapośredniczone w mechanizmach rynkowych i rynkopodobnych, to jednocześnie dzięki realizacji modelu państwa ewaluacyjnego kontrola sprawowana nad uniwersytetami publicznymi jest coraz silniejsza. Państwo dysponuje nie tylko narzędziami oceny i audytu, lecz określa również parametry sukcesu w finansowanej ze środków publicznych nauce, kreując i definiując to, co uważa się za „doskonałość”. Aktywność publicznych instytucji szkolnictwa wyższego w ramach krajowych rynków również nie jest wolna od ambiwalencji. Konkurują one nieustannie o status i uznanie, dążąc do wzmocnienia swojej przewagi konkurencyjnej właśnie poprzez zdobycze na tym polu. W szkolnictwie wyższym przedsięwzięcia o profilu wyłącznie kapitalistycznym i nastawionym na zysk najczęściej rezygnują z wyścigu o prestiż. Dlatego w czystej postaci stanowią wciąż jedynie jego margines.

\subsection{Przedsiębiorczy uniwersytet publiczny}

Ceniony badacz sektora szkolnictwa wyższego Guy Neave twierdzi, że wraz z opisanymi powyżej zmianami organizacyjnym, modelem odniesienia dla instytucji uniwersytetu, w miejsce średniowiecznej gildii, stało się „duże przedsiębiorstwo korporacyjne" (Neave 2011: 17). Myliłby się jednak ten, kto założyłby, że na gruncie głównego nurtu badań nad szkolnictwem wyższym jest to diagnoza jednoznacznie negatywna. Uniwersytet przedsiębiorczy to dla wielu badaczy figura ambiwalentna, łącząca tradycję akademicką oraz założenia uniwersyteckiej autonomii i kolegialności z rynkową skutecznością. Jest on też dziś z pewnością podstawą hegemonicznej normy, na realizację której ukierunkowane są procesy izomorfizmu instytucjonalnego uniwersytetów badawczych na całym świecie.

Pod koniec swojej pracy The Higher Education System Burton R. Clark podejmuje kwestię zmiany instytucjonalnej w sferze systemów szkolnictwa wyższego, wychodząc od tzw. paradoksu Hesburgha, głoszącego, że uniwersytet jako jedna z najstarszych instytucji społecznych świata zachodniego, jest bardzo odporny na zmiany i konserwatywny, a równocześnie znajduje się w awangardzie transformacji, które zaszły w społeczeństwie, będąc często również ich inicjatorem lub inspiratorem (Clark 1983: 182). Kreśląc trajektorię zmian w szkolnictwie wyższym, Clark zauważył, że zarówno dyscypliny, jak i instytucje składające się na dany system zmierzają w kierunku coraz większej złożoności (complexity) i zróżnicowania (differentiation). Dziesięć lat później stwierdzil, że ta rosnąca złożoność jest po prostu podstawowym aspektem dynamiki współczesnych systemów szkolnictwa wyższego (Clark 1993). Wobec uniwersytetów wysuwa się coraz więcej oczekiwań związanych z procesami umasowienia, a próby nacisku na ten sektor dokonywane są przez niemal wszystkie grupy społeczne. Rozszerzone zostały również oczekiwania wzglę- 
dem warunków i trybu kształcenia. Jak zauważa Clark, w obrębie systemów pojawiły się zróżnicowane kohorty studentów, a powrót do modelu kształcenia 3-5\% danej populacji w odpowiednim przedziale wiekowym wydaje się niemożliwy w żadnym z systemów szkolnictwa wyższego. We wszystkich dyscyplinach mamy bowiem do czynienia z coraz większym zapotrzebowaniem na wytwarzanie wiedzy i wyspecjalizowanych badań, jak również z coraz bardziej rozwiniętymi systemami ich produkcji. Następuje daleko posunięta specjalizacja i wyodrębnianie się nowych, coraz bardziej interdyscyplinarnych dziedzin wiedzy.

Na podstawie tak zarysowanej trajektorii przemian strukturalnych autor The Higher Education System wyodrębnia dwie ścieżki wzrostu, którymi mogą kroczyć instytucje szkolnictwa wyższego. Pierwszą z nich jest wzrost niezależny (substantive growth), często przeciwstawiany przez Clarka umasowieniu, drugą zaś wzrost reaktywny (reactive growth), koncentrujący się na rozroście kadr, infrastruktury czy rozmiarów systemu w odpowiedzi na rosnącą liczbę studentów. Jak pisze:

[...] niezależny wzrost prowadzi do wyłonienia się bardziej ezoterycznych specjalności akademickich, które organizacyjnie stają się enklawami elit; reaktywny wzrost wymaga struktur masowych oraz wielkiej ekspansji wprowadzającego i średniozaawansowanego kształcenia. Niezależny wzrost zachęca do rozwijania kształcenia na poziomie doktoranckim i programów studiów doktoranckich; wzrost reaktywny opiera się na wielkim rozszerzeniu kształcenia na niższych poziomach. Niezależny wzrost staje się naczelnym „wymogiem” w ramach jednego zbioru instytucji w zróżnicowanym systemie krajowym, podczas gdy reagowanie na konsumencki popyt staje się podstawowym czynnikiem w innym zbiorze (Clark 1996: 424).

Jak jednak w praktyce uniwersytety reagują na te strukturalne przemiany? W jaki sposób są w stanie opierać się wzrostowi reaktywnemu i wspierać wzrost niezależny?

W The Higher Education System Clark przypisuje czterem typom koordynacji systemu ${ }^{4}$ różne tryby dokonywania udanych przekształceń. W ten sposób zmiana dokonywana w systemie z dominantą koordynacji biurokratycznej odbywa się odgórnie, poprzez planowanie i administrację. Najczęściej przeprowadzana jest małymi krokami. W przypadku oligarchii akademickiej wpływ na system re-

4 W rozdziale V książki Clark (1983: 137-181) przedstawia „trójkąt koordynacji” systemów szkolnictwa wyższego. Jest to typ idealny układu sił w systemie szkolnictwa wyższego, mający obrazować procesy integracji i koordynacji systemów szkolnictwa wyższego na świecie. Jego krańce tworzone są przez państwo i aparat biurokratyczny, rynek i mechanizmy konkurencji oraz oligarchię akademicką i siły właściwe dla samoregulacji wspólnoty uczonych. Sytuacja między nimi jest dynamiczna, a instytucje szkolnictwa wyższego w ramach całych krajowych systemów rozgrywane są (i rozgrywają) w ramach tak zarysowanego pola sil. Raz podążają w stronę tego, następnym razem w stronę innego bieguna, nigdy jednak nie dochodzi do sytuacji, by ich położenie można było jednoznacznie przypisać do jednego z nich. Trójkąt koordynacji poddany został w literaturze licznym interpretacjom, krytykom i modyfikacjom. 
alizowany jest poprzez jednostkowe inicjatywy (np. dokonania wielkich rektorów) czy planowanie kolegialne. W ramach politycznej koordynacji zmiany dokonywane są poprzez walki grup interesu lub dominujący wpływ ciał politycznych w postaci partii, związków zawodowych czy urzędników państwowych. Siły rynkowe forsują natomiast zmiany przez wdrażanie zasad konkurencji między instytucjami oraz umożliwianie luźnych powiązań pozwalających instytucjom i sektorom poruszać się samodzielnie w różnych kierunkach (Clark 1983: 201-203).

Clark, chcąc wyjść poza tak rozumianą dynamikę zmiany, poszukuje praktyk, w których to instytucje szkolnictwa wyższego stałyby się prawdziwymi podmiotami własnej transformacji, samodzielnie określającymi zestawy własnych celów i służących im środków. Tego typu poszukiwania wynikają m.in. z założenia, które przyjęte zostało już w The Higher Education System, w podrozdziale poświęconym niezwykłej złożoności szkolnictwa wyższego jako systemu społecznego (Clark 1983: 276). Clark nazywa takie ujęcie „perspektywą organizacyjną”, wskazując, że wychodzi ono ze środka danego systemu społecznego i skupia się na tym, w jaki sposób on „działa i jak odpowiada na bodźce z zewnątrz, w jaki sposób utrzymuje stabilność oraz jak wdraża zmiany, jak również w jaki sposób podąża ścieżkami określanymi przez zewnętrznych aktorów" (Clark 1984: 106). Podobna perspektywa została przyjęta również w analizach składających się na książkę Creating Entrepreneurial Universities (Clark 1998), gdzie stawia tezę, że w warunkach rosnącej złożoności przedsięwzięcia akademickiego zdolne do rozwijania się w ramach niezależnego modelu wzrostu będą właśnie uniwersytety przedsiębiorcze. Zaproponowane przez niego pojęcie uniwersytetu przedsiębiorczego zrobiło wielką karierę (zarówno w dyskursach ustawodawczych, jak i naukowych) i, choć abstrakcyjne, posiadało jednak mocną empiryczną podstawę. Warto pokrótce przyjrzeć się elementom, które się na nią złożyły ${ }^{\text {. }}$

Clark twierdzi, że samo przyznanie autonomii instytucjonalnej, do której prowadzą różne reformy sektora szkolnictwa wyższego, nie gwarantuje jeszcze, że zajdzie proces samookreślenia tworzących go instytucji. Zauważa, że „autonomiczne uniwersytety stają się aktywnymi instytucjami, gdy decydują, że muszą eksplorować i eksperymentować ze zmianami dotyczącymi tego, w jaki sposób są złożone i jak mają reagować na wewnętrzne i zewnętrzne żądania" (Clark 1998: 5). Uniwersytet przedsiębiorczy jest zatem - w ujęciu Clarka - instytucją mającą „zdolność do zmiany". Jego istotą jest posiadanie zróżnicowanego portfela źródeł przychodów, pozwalającego uniezależnić się nie tylko od subwencji publicznych, firm i ich komercyjnego wpływu, ale również od czesnego studenckiego (Clark 2005: 2). Jak już ponad 50 lat temu pisali Homer Babbidge i Robert Rosenzweig (1962: 158), „dwudziestowieczna definicja autonomii instytucjonalnej to nieobecność zależno-

${ }^{5}$ Idea uniwersytetu przedsiębiorczego Clarka jest tu omówiona skrótowo. W polskiej literaturze, w kontekście empirycznym, wyczerpująco przedstawił ją Marek Kwiek (2010: 244-281). 
ści od jednej lub wąskiej bazy wsparcia”. Według Clarka w praktyce oznaczałoby to, że samosterowne i autonomiczne instytucjonalnie uniwersytety przedsiębiorcze powinny bilansować przychody z trzech podstawowych źródeł finansowania (dotacji publicznej, przychodów z działalności z sektorem prywatnym i uniwersyteckich sposobów generowania zysków oraz czesnego studenckiego) mniej więcej na poziomie 1/3 globalnej sumy przychodów. Ta równowaga stanowi przepis na efektywne zarządzanie instytucją uniwersytecką, które „zdaje się nie zależeć od państwa czy »rynku «, ale od uniwersyteckiego samokierowania się oraz samookreślenia” (Clark 2005: 3). To jednak sytuacja idealna i rzadko występuje w rzeczywistości.

Pojawia się jednak pytanie, jakie elementy instytucjonalne składają się na uniwersytet przedsiębiorczy? Zdaniem Clarka nieredukowalne minimum tworzy pięć składników. Po pierwsze, wzmocniony rdzeń kierowania (strengthened steering core), obejmujący centralne kierownictwo oraz wiodące wydziały nadające ton danej instytucji. Posiadanie tego rdzenia w przebadanych przez Clarka instytucjach było warunkiem ich rozwoju. Po drugie, poszerzone peryferia rozwojowe (expanded developmental peripheries), to znaczy takie jednostki uniwersytetu, które wchodzą w komunikację z zewnętrznymi organizacjami i grupami, stykają się z sektorem prywatnym i przedsiębiorstwami, zajmują się transferem wiedzy, kontaktem z przemysłem, rozwojem własności intelektualnej czy fundraisingiem. W skład tych poszerzonych peryferii rozwojowych mogą też wchodzić centra badawcze nastawione na pozyskiwanie funduszy $\mathrm{w}$ ramach szeroko zakrojonych projektów grantowych. Większość tego rodzaju wewnętrznych instytucji uniwersyteckich ukierunkowana jest na rozwiązywanie problemów praktycznych podsuwanych przez podmioty zewnętrzne, niezależnie od tego, czy są to firmy, czy agencje rządowe. Po trzecie, zdywersyfikowana podstawa finansowa (diversified funding base). Po czwarte, stymulujący rdzeń akademicki (stimulated academic heartland), który podtrzymuje wartości akademickie i akademicką kulturę. Zdaniem Clarka jest to właściwy podmiot stymulujący zmianę instytucjonalną na uniwersytecie. Po piąte, instytucjonalna kultura przedsiębiorczości (integrated eneterpeneurial culture) (Clark 2005: 8).

Przedsiębiorczy uniwersytet publiczny jawi się w świetle rozważań Clarka jako figura ambiwalentna. $Z$ jednej strony można w nim widzieć ratunek dla uniwersyteckiej autonomii (sprowadzanej przede wszystkim do autonomii od generowania przychodów i decydowania o formach tych przychodów) i mechanizm umożliwiający bardziej zdynamizowany rozwój instytucjonalny. $Z$ drugiej strony ta autonomia ma wymiar przede wszystkim finansowy i może kierować instytucje w stronę przyjęcia rynkowej racjonalności jako podstawy stosunków z własnymi pracownikami. Choć formalnie nienastawione na zysk, instytucje tego typu są wyraźnie zainteresowane generowaniem przychodów - najczęściej rozumianym jako tworzenie wartości dodatkowej z pracy dydaktycznej i usług podległych pracowników lub jako transfer wiedzy pod postacią własności intelektualnej. Należy również zwrócić uwa- 
gę, że przemieszczeniu w ramach uniwersytetu przedsiębiorczego podlegają procedury demokratyczne i kolegialne, a wzmocniony rdzeń kierowania danego uniwersytetu, składający się z władz uczelni, administracji oraz przedstawicieli najbardziej dynamicznych wydziałów, narzuca ton i kierunek jego rozwoju. W tym przypadku mamy do czynienia z postępującym podziałem pracy i zadań w ramach instytucji.

Analizując słabości ujęcia Clarka, warto wspomnieć również o głosach krytycznych, zwracających uwagę na dobór przykładów empirycznych do stworzonej wcześniej ramy teoretycznej (Deem 2001). Krytyka ta nie zmienia jednak faktu, że Clarkowi udało się stworzyć narzędzie teoretyczne o potężnym wpływie i oddziaływaniu, które, bez względu na jego empiryczną podstawę, stało się niemal matrycą współczesnych form zapośredniczonego ustawodawczo i politycznie instytucjonalnego izomorfizmu.

\subsection{Kapitalizm akademicki}

Innego, jeszcze szerszego, porównawczego podejścia do lokalnego rozwoju zjawisk przyczyniających się do hybrydyzacji porządków tego, co prywatne i tego, co publiczne w szkolnictwie wyższym dostarczyli teoretycy kapitalizmu akademickiego. Kapitalizm akademicki to zarówno przedmiot badania, jak i określona teoria, która, jak twierdzą Brendan Cantwell i Ilkka Kauppinen (2014: 6), oferuje z jednej strony ramę konceptualną, z drugiej zaś - narzędzia metodologiczne pozwalające na radzenie sobie z interesującymi nas zmianami. Możemy wyróżnić przynajmniej dwa elementy kapitalizmu akademickiego: 1) strukturalny - obejmujący zestawy neoliberalnych polityk w stosunku do sektora szkolnictwa wyższego i „sposoby organizowania go poprzez regulację, strumienie finansowania oraz wiązanie akademii z państwem i rynkiem”, 2) behawioralny - czyli „różnorodne zachowania rynkowe i rynkopodobne podejmowane przez polityków, administratorów, kadrę i studentów" (Cantwell i Kauppinen 2014: 5).

Począwszy od książki Academic Capitalism, Larry Leslie i Sheila Slaughter (1998) prowadzą badania nad zmianami, jakie zaszły w warunkach wykonywania pracy akademickiej na uniwersytetach publicznych w latach 1970-1995 w czterech krajach anglosaskich: Stanach Zjednoczonych, Wielkiej Brytanii, Australii i Kanadzie. We wszystkich tych krajach lata 8o. i zachodząca wówczas neoliberalna transformacja (w dwóch głównych - Stanach Zjednoczonych i Wielkiej Brytanii - związana z działaniami administracji Ronalda Reagana i Margaret Thatcher), oparta na cięciach w budżetach publicznych, reformach ukierunkowujących instytucje publiczne praktycznie, produkcyjnie i prorynkowo, oznaczała wiele zmian i zmniejszenie zasobów dostępnych dla systemów szkolnictwa wyższego jako całości, oraz dla poszczególnych tworzących go instytucji. Mieliśmy w tym czasie do czynienia z połączeniem rządowego planowania z ukierunkowaniem instytucji publicznych na sprzyjanie rozwojowi gospodarczemu (Ferlie i in. 2008). Autorzy 
twierdzą, że podobnie jak rewolucja przemysłowa w XIX wieku zmieniła warunki pracy na uniwersytetach, wzmagając rozwijanie misji badawczej uniwersytetów, profesjonalizację kadry i zapewniając zasoby umożliwiające rozrost szkolnictwa wyższego (głównie w Stanach Zjednoczonych), tak globalizacja (i kształtowanie się gospodarki opartej na wiedzy) jest siłą, która napędza kolejną rewolucję akademicką. Proces ten przyczynia się według Lesliego i Slaughter przede wszystkim do rozkładu profesji akademickiej ${ }^{6}$ [professionals, do grona których zaliczać się miała również kadra akademicka, w okresie rewolucji przemysłowej w Stanach Zjednoczonych starali się ulokować poza opozycją kapitał/praca (Ehrenreich i in. 1979), wyraźnie podkreślając, że ich działania są ukierunkowane na dobro publiczne oraz niemotywowane zyskiem]. Procesy te w sferze szkolnictwa wyższego doprowadziły do narodzin kapitalizmu akademickiego. Zaproponowane przez Slaughter i Leslie'ego pojęcie miało kluczowe znaczenie dla możliwości wykształcenia się naukowych i krytycznych dyskursów w ramach badań nad szkolnictwem wyższym.

Najogólniejsza definicja kapitalizmu akademickiego ${ }^{7}$, która pojawia się w wielu pracach tych badaczy, brzmi następująco: „kapitalizm akademicki to instytucjonalne oraz profesjonalne działania rynkowe i rynkopodobne mające na celu zapewnienie środków zewnętrznych" (Leslie i Slaughter 1998: 8)8. Należy od razu wyjaśnić, że działania rynkopodobne odnoszą się do konkurowania instytucji i kadry akademickiej o pieniądze od zewnętrznych dostawców zasobów (czy to prywatnych, czy publicznych), natomiast działania rynkowe - do aktywności stricte ukierunkowanych na zysk (for-profit), bez względu na to, czy są one bezpośrednio związane z którąś z podstawowych misji uniwersytetu, czy też ze zwykłą sprzedażą produktów na kampusie bądź wynajmowaniem przestrzeni.

Badając kształtowanie się kapitalizmu akademickiego, Leslie i Slaughter (1998: 9) zwracają uwagę na postępujące równolegle z tym procesami zacieranie się granicy między tym, co publiczne, a tym, co prywatne, w kontekście szkolnictwa wyższego przejawiające się właczeniem motywu zysku w działania kadry akademickiej czy prywatyzacji zysków z badań (kadra stająca się współwłaścicielami spółek typu spin-off czy firm capital venture niezależnych od uniwersytetów, na których podejmowała długoletnie i opłacane z publicznych pieniędzy badania), jak również upublicznianiu strat. Ze statystyk, na które powołują się autorzy, wynika, że przeciętnie jedno na dziesięć przedsiębiorczych działań typu spin-off przynosi korzyści finansowe w krótkim okresie, reszta nie przynosi go wcale lub jedynie w długim

${ }^{6}$ W tym samym okresie Garry Rhoades (1997) opublikował równie ciekawą książkę dotyczącą konsekwencji nowych form zarządzania uniwersytetami dla uzwiązkowionej kadry akademickiej.

7 Jak piszą autorzy, pojęcie kapitalizmu akademickiego jest dużo starsze niż ich propozycja. Genealogicznie rzecz ujmując, można je wyprowadzić już z tekstu Maxa Webera Nauka jako zawód i powotanie (1999).

${ }^{8}$ Identyczną definicję znajdziemy w wielu innych tekstach tych autorów (np. Slaughter i Rhoades 2004; 2006). 
okresie (Leslie i Slaughter 1998: 135) ${ }^{9}$. Kadra akademicka, będąc częścią sektora publicznego, otrzymując wysokie i najczęściej dające poczucie bezpieczeństwa wynagrodzenie, ma zatem możliwość działania niczym „subsydiowani przez państwo przedsiębiorcy" (Leslie i Slaughter 1998: 9). Warto przy tym zauważyć, że chociaż znaczna część dyskusji dotyczących uniwersytetów przedsiębiorczych czy zaangażowania w kapitalizm akademicki posługuje się retoryką rynkową, to większa część środków finansowych umożliwiających tę działalność w długiej perspektywie dostarczana jest przez państwo (Slaughter i Rhoades 2004: 306-309). Na podstawie procesów transferu technologii za pośrednictwem patentów zjawisko to omówili Jacob Rooksby i Brian Pusser, stwierdzając zarazem, że choć przedsięwzięcia określane jako „kapitalizm akademicki” mają z pewnością charakter akademicki, to „biorąc pod uwagę trwały brak zysku [po stronie instytucji akademickich - K. Sz.], można stwierdzić, że transfer technologii jest bardziej zbliżony do subsydiowania prywatnego rozwoju gospodarczego niż do wkroczenia organizacji szkolnictwa wyższego w kapitalizm" (Rooksby i Pusser 2014: 80). W zalążkowej formie mamy tu do czynienia z jednym z istotniejszych rozpoznań teorii kapitalizmu akademickiego dotyczących relacji między kapitałem a rzeczywistością szkolnictwa wyższego.

Wśród elementów postindustrialnych przekształceń szkolnictwa wyższego Leslie i Slaughter wyliczają m.in.: konkretne zmiany organizacyjne uczelni wyższych i powiązane z nimi zmiany w sposobach wewnętrznej (zarówno wobec systemu, jak i danych instytucji) alokacji zasobów; konkretne zmiany w podziale pracy, przede wszystkim jeśli chodzi o podział na badanie i kształcenie; ustanowienie nowych struktur administracyjnych na uniwersytetach. Motywacja, która stoi za podejmowaniem działań ukierunkowanych na tego rodzaju przekształcenia, bierze się z wpływu "globalizacji” (autorzy tym pojemnym terminem określają wszystkie czynniki związane z przekształceniami społeczno-polityczno-gospodarczymi) na szkolnictwo wyższe, manifestującego się: 1) ograniczeniem funduszy z budżetów krajowych przeznaczanych na szkolnictwo wyższe; 2) rosnącym znaczeniem technonauki i obszarów wiedzy ściśle związanych z rynkiem; 3) zacieśnianiem więzi między korporacjami a agencjami rządowymi skupionymi na rozwijaniu produktów i innowacji; 4) coraz większą uwagą rozwiniętych krajów i korporacji kierowaną na prawa własności intelektualnej (Leslie i Slaughter 1998: 39).

W każdym z badanych przez Lesliego i Slaughter krajów zestaw rozwiązań ustawowych związany z zachęcaniem do podejmowania działań w ramach kapitalizmu

${ }^{9}$ Choć dane podawane przez amerykańskich badaczy pochodzą sprzed niemal 20 lat, to podobne wnioski, oparte na współczesnych danych statystycznych, przedstawia Elisabeth Popp Berman (2012: 94-118). Rooksby i Pusser (2014: 87) piszą w tym kontekście o „niechętnym kapitalizmie akademickim”. Podobne spostrzeżenia pojawiają się już we wczesnych tekstach autorów teorii kapitalizmu akademickiego (Slaughter i Rhoades 1993; 1996). 
akademickiego „zmierzał do zwiększenia krajowej konkurencyjności gospodarczej; troszczył się o wytwór i proces innowacji, przekierowując studentów i zasoby do dobrze przygotowanych programów, które potrafią sprostać wymogom globalnego rynku, trenując większą liczbę studentów dla postindustrialnych miejsc pracy, mniejszym kosztem, oraz starając się zarządzać kadrą i pracą instytucjonalną w bardziej wydajny i efektywny sposób” (Leslie i Slaughter 1998: 63).

W swoich badaniach Leslie i Slaughter posługiwali się przede wszystkim teorią zależności od zasobów, rozwiniętą przez Jeffreya Pfeffera i Geralda Salancika (2003), aby sprawdzić, czy instytucje szkolnictwa wyższego przystosowywały się do nowych ograniczeń finansowych, wypracowując źródła przychodów oparte na zaangażowaniu w kapitalizm akademicki. Mamy tu do czynienia ze spostrzeżeniem, które poczynił w tym samym czasie Burton Clark: im mniej źródeł zasobów, tym większą władzę nad instytucją sprawuje ich główny dostarczyciel. Dostawcy zasobów sprawują pośrednią i bezpośrednią władzę nad wewnętrznymi zachowaniami organizacyjnymi i to właśnie zmiany trybu i modeli finansowania oraz zmniejszenie nakładów na szkolnictwo wyższe są przyczyną pojawienia się kapitalizmu akademickiego (Leslie i Slaughter 1998: 79). Jednocześnie tego typu działania nie zwiększają, lecz zmniejszają autonomię publicznych instytucji szkolnictwa wyższego.

Omawiając problemy i konflikty generowane przez przesunięcie się z reżimu wiedzy/kształcenia jako dobra publicznego do reżimu kapitalizmu akademickiego, Slaughter i Rhoades (2004: 329) zauważyli, że doszło do zatarcia granicy między sektorem publicznym i prywatnym, przy jednoczesnym zachowaniu istotnego finansowania publicznego przedsięwzięć i aktywności rynkowych oraz rynkopodobnych instytucji akademickich i zatrudnionej w nich kadry. Częścią tego zjawiska jest postępująca redefinicja przestrzeni publicznej na uniwersytetach, która coraz częściej przyjmuje cechy przestrzeni komercyjnej. Co więcej, jak wskazują Slaughter i Rhoades, przedsięwzięcia związane z kapitalizmem akademickim rzadko, jeśli w ogóle, generują dla instytucji wysoki przychód netto. Poza tym ograniczenie celów instytucji do poszukiwania dodatkowych przychodów, szczególnie gdy ukierunkowane jest na działania na poziomie globalnym, redukuje zaangażowanie instytucji na rzecz wspólnot lokalnych, w ramach których na co dzień funkcjonują.

Podsumowując, możemy stwierdzić, że teoretykom kapitalizmu akademickiego dość precyzyjnie udało się ukazać przejście od bezpośredniej kontroli państwowej nad systemami szkolnictwa wyższego do kontroli państwowej zapośredniczonej w mechanizmach rynkowych (Leslie i Slaughter 1998: 228). Ich perspektywa wydaje się jednak ograniczona, ponieważ zakłada, że zatarte przez kapitalizm akademicki granice między tym, co prywatne a tym, co publiczne można przywrócić w dawnej formie. Diagnozując nową formę sprawowania władzy (obecną nie tylko w sektorze szkolnictwa wyższego), autorzy reprezentujący tę perspektywę dochodzą do wniosku, że odpowiedzi na rosnące problemy należy szukać w powrocie do tego, co publiczne. 
Trzeba jednak zauważyć, że rozwijana przez teoretyków kapitalizmu akademickiego krytyczna perspektywa podejmująca kwestie zawiłych relacji związanych z urynkowieniem uniwersytetów, rozumianym nie tylko jako interwencja zewnętrznego porządku (rynku/korporacji/kapitału), ale również jako działalność funkcjonujących w obrębie uniwersytetu podmiotów, stanie się punktem wyjścia do rozwijania zarówno badań w obrębie interesującego nas nurtu krytycznego, jak i projektu problematyzacji porównawczych badań nad szkolnictwem wyższym głównego nurtu.

Podobnie jak Simon Marginson (2015), europejski teoretyk kapitalizmu akademickiego Richard Münch (2014) wychodzi z założenia, że reformy w paradygmacie Nowego Zarządzania Publicznego, odpowiedzialne za upowszechnienie się kapitalizmu akademickiego w Europie nie doprowadziły (i nie mogły doprowadzić) do uformowania się w systemach szkolnictwa wyższego rynków w sensie kapitalistycznym. Co więcej, tworzenie quasi-rynków w szkolnictwie wyższym, zamiast zwiększyć konkurencyjność i zróżnicować systemy, sprzyja przede wszystkim praktykom monopolowym. Münch, inaczej niż Sheila Slaughter i Larry Leslie, twierdzi, że za powstanie i upowszechnienie się kapitalizmu akademickiego odpowiedzialne jest nie względne zmniejszenie dostępnych środków publicznych związane z postępującym umasowieniem szkolnictwa wyższego, lecz globalna hegemonia neoliberalna sprawowana w sferze dyskursu reform (Münch 2014; podobnego zdania są również Filippakou i Williams 2014: 81). Tym jednak, co najbardziej wyróżnia analizy tego autora, jest wskazanie na znaczenie procesów akumulacji i pomnażania kapitału społecznego i symbolicznego w rzeczywistości kapitalizmu akademickiego. Uniwersytety przedsiębiorcze nie robią „po prostu” pieniędzy - nie zajmują się przede wszystkim równoważeniem swoich budżetów, lecz równoważeniem relacji między pomnażaniem kapitału symbolicznego (poprzez zwiększanie swojej widzialności i zlokalizowanego w instytucji prestiżu) a pomnażaniem kapitału ekonomicznego (korzystania z wynikłych ze zwiększenia prestiżu szans pozyskiwania środków publicznych na badania, współpracy z biznesem czy przyciągania najlepszych, kształcących się odpłatnie studentów; por. Marginson i Considine 2000: 3-12; 233-255).

Teoria kapitalizmu nastręcza jeszcze wielu innych problemów. Sheila Slaughter, podsumowując blisko 20 lat rozwoju tego paradygmatu stwierdziła, że największym paradoksem związanym z jego wypracowywaniem i recepcją było to, że „liczni czytelnicy przegapili zawartą w książce [Academic Capitalism - K. Sz.] krytykę, traktując ją jak podręcznik wdrożeniowy" (Slaughter 2014: viii). Nie inaczej twierdzi Garry Rhoades (2014: 114), zauważając, że „kapitalizm akademicki, podobnie jak kapitalizm w ogóle, dotyczy władzy zakorzenionej w społecznych stosunkach produkcji. Dotyczy nie tylko »rozszerzonej zdolności menedżerskiej «, ale również wysiłków mających na celu rozszerzanie kontroli menedżerskiej oraz kolektywnych walk prowadzonych przeciwko tym staraniom". 


\section{Ograniczenia tezy o hybrydyzacji tego, co publiczne i tego, co prywatne w szkolnictwie wyższym}

Czy zatem, jak zdaje się sugerować Robert Zemsky (2004: B7), pod naciskiem przekształconych w klientelę studentów oraz władz różnego szczebla, a także globalną presją, by zmienić uniwersytety w motory wzrostu gospodarczego w epoce gospodarki opartej na wiedzy, to, co publiczne, zostało dziś bezpowrotnie utracone? Opisane wyżej przemiany, zarówno w relacjach między państwem a sektorem szkolnictwa wyższego, jak również te dotyczące właczania się publicznych instytucji szkolnictwa wyższego w rozwijające się rynki i quasi-rynki, a także wzmagająca się presja wywierana różnymi sposobami na instytucje, by stawały się coraz bardziej przedsiębiorcze, sprawiają, że coraz więcej badaczy podziela niepokój Zemsky'ego. Jednocześnie podkreśla się ambiwalentny charakter podziału na to, co publiczne i to, co prywatne w kontekście współczesnych instytucji szkolnictwa wyższego (Marginson 2007b: 187). W pewnym bowiem sensie, jak pisze Marek Kwiek (2010: 247), możemy dziś mówić o „połączeniu trajektorii zmian instytucji prywatnych i publicznych". Za Peterem Maassenem i Johanem P. Olsenem (2007) można zauważyć, że na poziomie dyskursywnym konstrukcja współczesnych instytucji szkolnictwa wyższego rozpięta jest między wizją „uniwersytetu jako przedsiębiorstwa usługowego wcielonego w konkurencyjne rynki” a modelem „uniwersytetu jako narzędzia realizacji zmieniających się agend politycznych”, najczęściej zresztą ukierunkowanego na ekonomiczny rozwój.

$\mathrm{W}$ tym miejscu konieczne jest przedstawienie, konkretyzacja i przekroczenie stawianej przez niektórych przedstawicieli głównego nurtu badań szkolnictwa wyższego hipotezy o hybrydyzacji tego, co publiczne i tego, co prywatne w tym sektorze.

Ceniony badacz prywatnego sektora szkolnictwa wyższego Daniel Levy (1980) słusznie wskazuje, że rozróżnianie na instytucje prywatne i publiczne na podstawie ich formalnego statusu często bywa mylące. Zresztą sama kwestia ambiwalencji między tym, co publiczne a tym, co prywatne nie jest wyłącznie domeną sektora szkolnictwa wyższego. Levy uważa, że w celu oszacowania, czy dana instytucja jest publiczna, czy prywatna, musielibyśmy posłużyć się biegunowo różnymi typami idealnymi jednej i drugiej, aby możliwe było dokonanie oceny, do której kategorii jej bliżej (Levy 1980: 15). Swój typ idealny instytucji prywatnej/publicznej Levy buduje w odniesieniu do trzech kategorii: finansów, rządzenia (governance) i funkcji. Instytucja jest zatem prywatna w takim stopniu, w jakim źródła jej finansów są inne niż pochodzące od państwa, publiczna natomiast - jeśli musi polegać przede wszystkim na środkach publicznych (Levy 1980: 16). Kryterium dotyczące rządzenia wskazuje, że dana instytucja jest prywatna w stopniu, w którym zarządza nią niepaństwowy personel, a publiczna w stopniu, w którym kieruje nią państwo. Jeśli 
zaś idzie o funkcje, czyli to, co uniwersytet czy instytucja szkolnictwa robi lub to, czym jest w tych działaniach ograniczona, to rozróżnienie na prywatne i ubliczne dokonywane jest w odniesieniu do tego, jakim klientom służy instytucja, jakie wartości oraz ideologie szerzy i realizuje w procesie kształcenia itd.

Jednak jeśli przyjrzymy się współczesnym instytucjom szkolnictwa wyższego pod kątem pierwszego kryterium Levy'ego to zobaczymy, że zarówno te, które są całkowicie wolne od publicznego finansowania, jak również te, które zależą w dużej mierze od państwowych środków, powoli zaczynają stanowić mniejszość. Ze statystyk obrazujących strukturę finansowania europejskich uniwersytetów publicznych w 2008 r. wynika, że istnieje wiele systemów, w których blisko połowa lub ponad połowa środków na działanie instytucji pochodzi ze studenckiego czesnego i zdobywanych na konkurencyjnej podstawie środków na badania (publicznych i prywatnych ${ }^{10}$, a publiczne uniwersytety finansujące się niemal wyłącznie poprzez operacyjne finansowanie publiczne stanowią raczej niewielką grupę ${ }^{11}$. Co więcej, jeśli uwzględnimy procesy włączania w struktury uniwersyteckiego rządzenia różnego rodzaju interesariuszy, w tym przedstawicieli prywatnych firm i przedsiębiorstw, oraz coraz szerzej zakrojoną profesjonalizację administracji i kierownictwa na uczelniach, wówczas i dwa pozostałe kryteria Levy'ego niewiele nam pomogą. Wszystkie te czynniki sprawiają, że nawet tak ścisłe kryteria oceny prywatności/ publiczności instytucji, jak te używane przez Levy'ego, okazują się obecnie mało adekwatne w odniesieniu do dużej grupy instytucji lokujących się pośrodku skali rozpiętej między biegunami wyznaczanymi przez zarysowane tu typy idealne.

Co więcej, w kontekście brytyjskim i portugalskim - jak wskazują Alberto Amaral i Antonio Magalhaes (2007: 103) (12 $^{12}$ gdy zmniejsza się finansowanie publiczne i zaostrza rywalizacja o dostępne środki, uniwersytety publiczne zachowują się podobnie jak instytucje prywatne i uczestniczą w „quasi-rynkowym pościgu” za przychodami, bez żalu porzucając wszelkie elementów swojej publicznej misji i związaną z nią dbałość o jakość kształcenia. Rządząca ich działaniem (jak również instytucjami sektora formalnie prywatnego) zasada „wewnętrznej skuteczności”, głosząca, że należy „wytwarzać odpowiedni pakiet produktów, biorąc pod uwagę potrzeby i pragnienia interesariuszy, przy jednoczesnym minimalizowaniu kosztów produkcji dla danego pakietu" (Massy 2004: 15), odpowiedzialna jest za stopniowe upodabniania instytucji publicznych szkolnictwa wyższego do firm, w których rela-

${ }^{10} \mathrm{~W}$ takiej sytuacji znajduje się 9 z 27 przebadanych systemów. Średnia europejska dla finansowania z publicznych dotacji operacyjnych wynosi $67 \%$ całkowitego budżetu (Jongbloed i de Boer 2012: 134).

${ }^{11}$ Jeśli weźmiemy pod uwagę kraje, w których finansowanie uniwersytetów publicznych w postaci grantów operacyjnych płynących ze strony władz publicznych stanowi blisko lub ponad $90 \%$ całości budżetów, to w tym gronie znajdą się wyłącznie: Malta (95\%), Słowacja (94\%), Luksemburg (92\%) i Szwecja (88\%) (Jongbloed i de Boer 2012: 134).

${ }^{12}$ Testując hipotezę wsuniętą przez Williama Massy'ego (2004: 25-30). 
cje pomiędzy kierownictwem a podwładnymi odpowiadają relacjom między pracą a kapitałem.

Czy wobec tego proces hybrydyzacji może napotkać jakąś granicę? Czy to, co publiczne może oprzeć się w jakimś stopniu tendencjom do podporządkowania, urynkowienia i komercjalizacji?

W odpowiedzi na negatywne konsekwencje omówionych wyżej procesów badacze formułują różnego rodzaju alternatywy. Marginson (2015) dowodzi niemożliwości (i całkowitej nieskuteczności) kapitalistycznych rynków w sektorze szkolnictwa wyższego, domagając się jednocześnie powrotu do faktycznie publicznego systemu w kontekście funkcjonowania uniwersytetów publicznych. Co taki powrót miałaby jednak w praktyce oznaczać? Ścieżka ścisłej biurokratycznej kontroli wydaje się dzisiaj, w epoce skomplikowanych i umasowionych systemów, zamknięta. Wykształcona wobec niej alternatywa państwa ewaluacyjnego, stosująca w odniesieniu do sektora publicznego quasi-prawo wartości jako prawo koordynacji i zachowywania wewnętrznej równowagi, również nie jest zachęcająca.

Jakkolwiek nie byłyby formułowane, wszystkie postulaty dotyczące ponownego „upublicznienia” publicznych uniwersytetów wydają się o tyle złudne, że mają problem ze wskazaniem podmiotu tej zmiany. Spytajmy otwarcie: skoro przez ostatnie dekady w sektorze publicznym na całym świecie rządy dokonywały reform podporządkowujących ten sektor, a więc również publiczne szkolnictwo wyższe, coraz bardziej potrzebom rynku, przy niemal niezmąconej społecznej akceptacji dla tego faktu, to kto dziś miałby być zainteresowany odwracaniem wektora tych procesów? To kluczowe pytanie na gruncie badań nad szkolnictwem wyższym głównego nurtu pozostaje bez odpowiedzi.

Podsumowując, należy zauważyć, że hybrydyzacja tego, co prywatne i tego, co publiczne jest procesem, w ramach którego formalnie publiczne instytucje zyskują coraz dalej posuniętą autonomię (finansową, organizacyjną, zatrudnieniową). Jednocześnie ze sfery polityki publicznej nieustannie płyną zachęty do zachowań przedsiębiorczych, ukierunkowanych na współpracę ze sferą gospodarczą. Instytucje tworzące publiczną część sektora szkolnictwa wyższego uczestniczą więc jako aktywne podmioty w różnego rodzaju rynkach tworzonych i powstających samorzutnie w ramach sektora, oraz działają według zasady „wewnętrznej skuteczności” nakazującej nieustannie redukować koszty własnej działalności i rozszerzać zakres dostępnych źródeł przychodów. Tak rozumiana hybrydyzacja, nieodcinająca ostatecznie publicznego sektora szkolnictwa wyższego ani od ścisłej kontroli państwowej wyznaczającej mu stale priorytety korzystne dla rozwoju kapitalistycznej gospodarki, ani od publicznego finansowania umożliwiającego amortyzację ryzyka właściwego inwestycjom w sferze innowacji i rozwoju, jest zjawiskiem funkcjonalnym wobec procesów pomnażania kapitału w sferze produkcji wiedzy. Co więcej, jest to zjawisko przez kapitał jak najbardziej pożądane. Hybrydyzacja porządków tego, co publiczne i tego, co prywatne to zatem nie tyle stan przejściowy między 
ścisłą publiczną kontrolą sektora a jego kompletną prywatyzacją i podporządkowaniem rynkowi, ale właściwy, zapośredniczony w instytucji neoliberalnego państwa stan organizacji stosunków między szkolnictwem wyższym a kapitałem, odpowiadający potrzebom jego pomnażania i akumulacji.

Choć w ramach badań nad szkolnictwem głównego nurtu udało się naświetlić to zjawisko z wielu perspektyw i wskazać wiele wynikających z niego negatywnych konsekwencji, to horyzont liberalnej filozofii politycznej i ekonomii neoklasycznej, który wyznacza granice wyobraźni w tym polu badań, nie daje narzędzi umożliwiających rozwiązanie problemów trapiących współczesne szkolnictwo wyższe. Potrzebna jest wobec tego rama analityczna, która pozwoliłaby na przedstawienie tego procesu w innym świetle, być może przyczyniając się w ten sposób do reorganizacji sektora poprzez walkę z podporządkowaniem akademii i wszystkich innych obszarów życia społecznego dyktatowi kapitału. Tylko przez ukazanie procesu hybrydyzacji tego, co publiczne i tego, co prywatne jako konsekwencji większego konfliktu między zagrożonym dobrem wspólnym a rozwijającym się na tej podstawie kapitałem możemy doprowadzić do przełomu w relacjach między państwem, rynkiem, uniwersytetem a przecinającą te wszystkie porządki produktywną wielością. Kolejnym krokiem na drodze poszukiwań tej nowej ramy analitycznej mogaby być analiza współczesnych transformacji uniwersytetu w świetle Marksowskiego pojęcia subsumcji pracy kapitałowi. Temat ten jednak zasługuje na osobne rozważania $^{13}$.

\section{Literatura}

Aaviksoo, J. (2005). Public responsibility for research and access to research results. W: L. Weber, S. Bergan (red.), The Public Responsibility for Higher Education (163-170). Strasbourg: Council of Europe Publishing.

Althusser, L. (2000). Ideologie i aparaty ideologiczne państwa. Wskazówki do badań. Tłum. A. Staroń. Nowa Krytyka. http://www.nowakrytyka.pl/spip.php?article374 [31.08. 2015].

Amaral, A., Magalhaes, A. (2007). Market Competition, Public Good, and State Interference. W: J. Enders, B. Jongbloed (red.), Public-Private Dynamics in Higher Education (89-112). Bielefeld: Transcript.

Antonowicz, D. (2004). Z tradycji w nowoczesność. Brytyjskie uniwersytety w drodze do społeczeństwa wiedzy. Nauka i Szkolnictwo Wyższe. 1(23): 111-124.

Antonowicz, D. (2011). Problem interdyscyplinarności na przykładzie rozwoju oraz instytucjonalizacji badań nad szkolnictwem wyższym. W: A. Chmielewski, M. Dudzikowa,

${ }^{13}$ Tekst powstał w ramach mojej pracy w projekcie badawczym „Europejskie uniwersytety flagowe: w poszukiwaniu równowagi między doskonałością akademicką a zobowiązaniami wobec społeczeństwa i gospodarki (FLAGSHIP)" finansowanym ze środków Narodowego Centrum Nauki (UMO-2013/10/M/HS6/00561). 
A. Grobler (red.), Interdyscyplinarnie o interdyscyplinarności. Między teorią a praktyką (311-337). Kraków: Oficyna Wydawnicza Impuls.

Babbidge, H.D., Rosenzweig, R. (1962). The Federal Interest in Higher Education. New York: Literary Licensing.

Ball, S.J. (2003). The teacher's soul and the terrors of performativity. Journal of Education Policy. 18(2): 215-228.

Barnett, R. (2012). Imagining the University. New York: Routledge.

Berman, E.P. (2012). Creating the Market University. How Academic Science Became an Economic Engine. Princeton: Princeton University Press.

Bleiklie, I. (1999). The University, the State, and Civil Society. Higher Education in Europe. 24(4): 509-526.

Brenneis, D., Shore, C., Wright, S. (2005). Getting the Measure of Academia: Universities and the Politics of Accountability. Anthropology in Action. 12(1): 1-10.

Bruno, I. (2011). Zarządzanie kreatywnością społeczną przez benchmarking. Od menedżmentu Xeroxa do „Innowacyjnej Europy”. Tłum. A. Wojczyńska. W: M. Kozłowski, A. Kurant, J. Sowa, K. Szadkowski, K. Szreder (red.), Wieczna radość. Ekonomia polityczna społecznej kreatywności (239-253). Warszawa: Fundacja Bęc Zmiana.

Calhoun, C. (2006). The Universities and the Public Sphere. Thesis Eleven. 84: 7-43.

Callinicos, A. (2006). Universities in a neoliberal world. London: Socialist Workers Party.

Cantwell, B., Kauppinen, I. (red.) (2014). Academic Capitalism in the Age of Globalization, Baltimore: The Johns Hopkins University Press.

Clark, B.R. (1983). The Higher Education System. Academic Organization in Cross-National Perspective. Berkeley: University of California Press.

Clark, B.R. (1984). The Organizational Conception. W: B.R. Clark (red.), The Perspectives on Higher Education. Eight Disciplinary and Comparative Views (106-131). Berkeley: University of California Press.

Clark, B.R. (1993). The problem of complexity in modern higher education. W: Sh. Rothblatt, B. Wittrock (red.), The European and American university since 18oo. Historical and sociological essays. Cambridge: Cambridge University Press.

Clark, B.R. (1996). Substantive Growth and Innovative Organization. New Categories for Higher Education Research. Higher Education. 32: 417-430.

Clark, B.R. (1998). Creating Entrepreneurial Universities. Organizational Pathways of Transformation. Bingley: IAU Press.

Clark, B.R. (2004). Sustaining Change in Universities. Continuities in case studies and concepts. Berkshire: Open University Press.

Clark, B.R. (2005). The Character of Entrepreneurial University. International Higher Education. 38: 2-8.

Czarnecki, K. (2013). Nowe Zarządzanie Publiczne a reforma szkolnictwa wyższego w Polsce. Praktyka Teoretyczna. 1(7): 85-106.

Deem, R. (2001). Globalisation, New Managerialism, Academic Capitalism and Entrepreneurialism in Universities: is local dimension still important? Comparative Education. 37(1): 7-20.

Dow, S.C. (1990). Beyond dualism. Cambridge Journal of Economics. 14(2): 143-157. 
Dumenil, L. (2009). Neoliberalna (kontr-)rewolucja. Tłum. P. Listwan. W: L. Dumenil, Neoliberalizm przed trybunałem (25-40). Warszawa: Książka i Prasa.

Enders, J., Jongbloed, B. (2007). The Public, the Private and the Good in Higher Education and Research: an Introduction. W: J. Enders, B. Jongbloed (red.), Public-Private Dynamics in Higher Education. Expectations, Development and Outcomes (9-36). Bielefeld: Transcript.

Ferlie, E., Musselin, Ch., Andresani, G. (2008). The Steering of Higher Education Systems. A Public Management Perspective. Higher Education. 56(3): 325-348.

Filippakou, O. (2015). Higher Education As a Public Good: Notes for a Discussion. W: O. Filippakou, G. Williams (red.), Higher Education as a Public Good. Critical Perspectives on Theory, Policy and Practice (3-15). New York: Peter Lang.

Filippakou, O., Williams, G. (2014). Academic Capitalism and Entrepreneurial Universities as a New Paradigm of Development. Open Review of Educational Research. 1(1): 70-83.

Filippakou, O., Williams, G., (red.) (2015). Higher Education as a Public Good. Critical Perspectives on Theory, Policy and Practice. New York: Peter Lang.

Flew, T. (2014). Six theories of neoliberalism. Thesis Eleven. 122(1): 49-71.

Gornitzka, A., Maassen, P. (2007). An Instrument for National Political Agendas. The Hierarchical Vision. W: P. Maassen, J.P. Olsen (red.), University Dynamics and European Integration (81-98). Dordrecht: Springer.

Gramsci, A. (1961a). Nowoczesny książę. Tłum. B. Sieroszewska. W: A. Gramsci, Pisma wybrane (t. 1: 488-626). Warszawa: Książka i Wiedza.

Gramsci, A. (1961b). Amerykanizm i fordyzm. Tłum. B. Sieroszewska. W: A. Gramsci, Pisma wybrane (t. 2: 103-150). Warszawa: Książka i Wiedza.

Hardt, M., Negri, A. (2012). Rzecz-pospolita. Poza własność prywatna i dobro publiczne. Tłum. Praktyka Teoretyczna. Kraków: Wyd. Korporacja Ha!art.

Harvey, D. (1990). The Condition of Postmodernity. An Enquiry into the Origins of Cultural Change. Cambridge: Cambridge University Press.

Harvey, D. (2008). Neoliberalizm. Historia katastrofy. Tłum. T. Listwan. Warszawa: Książka i Prasa.

Hazelkorn, E. (2008). Learning to live with league tables and ranking: The experience of institutional leaders. Higher Education Policy. 21: 193-215.

Hazelkorn, E. (2011). Rankings and the Reshaping of Higher Education. The Battle for World-Class Excellence: Basingstoke: Palgrave.

Holley, K. (2006). Defining Governance for Public Higher Education in Twenty-First Century. W: W.G. Tierney (red.), Governance and the Public Good (199-206). New York: State University of New York Press.

Hood, C. (1996). Exploring Variations in Public Management Reform of the 1980s. W: H. Bekke, J.L. Perry, T. Thoonen (red.), Civil Service Systems in Comparative Perspective (268-287). Bloomington: Indiana University Press.

Jongbloed, B. (2003). Marketisation in Higher Education. Clark's Triangle and the Essential Ingredients of Markets. Higher Education Quarterly. 57(2): 110-135.

Jongbloed, B. (2007). Creating Public-Private Dynamics in Higher Education Funding: A Discussion of Three Options. W: J. Enders, B. Jongbloed (red.), Public-Private Dyna- 
mics in Higher Education. Expectations, Development and Outcomes (113-138). Bielefeld: Transcript.

Jongbloed, B., Boer, H. de (2012). Higher Education Funding Reforms in Europe and the 2006 Modernisation Agenda. W: M. Kwiek, A. Kurkiewicz (red.), The Modernisation of European Universities: Corss-National Academic Perspectives (127-148). Frankfurt am Main: Peter Lang.

Kauppinen, I. (2012). Towards transnational academic capitalism. Higher Education. 64: $543-556$.

KE (2006). Delivering on the Modernisation Agenda for Universities. Education, Research and Innovation. Brussels. COM 208 final.

KE (2011). Supporting growth and jobs - an agenda for the modernization of Europe's higher education systems. Brussels. COM 567.

King, R. (2007). Governance and accountability in the higher education regulatory state. Higher Education. 53: 411-430.

King, R. (2009). Governing Universities Globally. Organizations, Regulation and Rankings. Cheltenham: Edward Elgar.

King, R., Marginson, S., Naidoo, R. (red.) (2011). Handbook on Globalization and Higher Education. Cheltenham: Edward Elgar.

King, R., Marginson, S., Naidoo, R. (red.) (2013). The Globalization of Higher Education. Cheltenham: Edward Elgar.

Kruszelnicki, M. (2010). Uniwersytet jako wspólnota audytowanych. W: M. Jaworska-Witkowska, L. Witkowski (red.), Przeszkody dla rozwoju humanistyki w szkołach wyższych (z pedagogika w tle) (26-37). Toruń: Wyd. Adam Marszałek.

Krücken, G. (2003). Learning the New, New Thing: On the role of path dependency in university structures. Higher Education. 46(3): 315-339.

Kwiek, M. (2001). Globalization and Higher Education. Higher Education in Europe. 26(1): 27-38.

Kwiek, M. (2005). The University and the State in a Global Age. Renegotiating the Traditional Social Contract? European Educational Research Journal. 4(4): 324-341.

Kwiek, M. (2006). The University and the State. A Study into Global Transformations. Frankfurt am Main: Peter Lang.

Kwiek, M. (2010). Transformacje uniwersytetu. Zmiany instytucjonalne i ewolucje polityki edukacyjnej w Europie. Poznań: Wyd. Naukowe UAM.

Kwiek, M. (2014). Reforming European Universities: the Welfare State as a Missing Context. W: P. Zgaga, U. Teichler, H.G. Schuetze (red.), Higher Education Reform - Looking Back - Looking Forward (93-118). Rotterdam: Sense.

Latour, B. (2011). Nigdy nie byliśmy nowocześni. Studium z antropologii symetrycznej. Tłum. M. Gdula. Warszawa: Oficyna Naukowa.

Leslie, L., Slaughter, S. (1998). Academic Capitalism. Politics, Policies and Entrepreneurial University. Baltimore: The Johns Hopkins University Press.

Levy, D.C. (1980). University and Government in México. Autonomy in an Authoritarian System. New York: Praeger Publishers.

Lo, W.Y.W. (2014). University Rankings. Implications for Higher Education in Taiwan. Dordrecht: Springer. 
Locke, W. (2013). The Intensification of Rankings Logic in an Increasingly Marketised Higher Education Environment. European Journal of Education. 49(1): 77-90.

Lukes, S. (2005). Power. A Radical View. Houndmills: Palgrave.

Maassen, P., Olsen, J.P. (2007). European Debates on the Knowledge Institution. The Modernization of the University at the European Level. W: P. Maassen, J.P. Olsen (red.), University Dynamics and European Integration (3-23). Dordrecht: Springer.

Marginson, S. (1997). Markets in Education. Sydney: Allen and Unwin.

Marginson, S. (1997b). Steering from a distance: Power relations in Australian higher education. Higher Education. 34: 63-80.

Marginson, S. (2004a). Competition and Markets in Higher Education: A glonacal analysis. Policy Futures in Education. 2(2): 175-244.

Marginson, S. (2006). Putting Public Back into the Public University. Thesis Eleven. 84: 44-59.

Marginson, S. (2007a). The Public/Private Divide in Higher Education: A Global Revision. Higher Education. 53(3): 307-333.

Marginson, S. (2007b). Five Somersaults in Enschade: Rethinking Public/Private in Higher Education for the Global Era. W: J. Enders, B. Jongbloed (red.), Public-Private Dynamics in Higher Education. Expectations, Development and Outcomes (187-219). Bielefeld: Transcript.

Marginson, S. (2011). Strategising and ordering the global. W: R. King, S. Marginson, R. Naidoo (red.), Handbook on Globalization and Higher Education (394-414). Cheltenham: Edward Elgar.

Marginson, S. (2015). O niemożliwości zaistnienia kapitalistycznych rynków w szkolnictwie wyższym. Tłum. K. Szadkowski Nauka i Szkolnictwo Wyższe. 1(45): 11-37.

Marginson, S., Considine, M. (2000). The Enterprise University: power, governance and reinvention in Australia. Cambridge: Cambridge University Press.

Marginson, S., Ordorika, I. (2011). „El central volume de la fuerza”. Global Hegemony in Higher Education and Resaerch. W: D. Rhoten, C. Calhoun (red.), Knowledge Matters. The Public Mission of the Research University (67-129). New York: Columbia University Press.

Marginson, S., Rhoades, G. (2002). Beyond National States, Markets, and Systems of Higher Education: a glonacal agency heuristic. Higher Education. 43: 281-309.

Marginson, S., Wende, M. van der (2007) Globalization and Higher Education. Paris: OECD.

Marginson, S., van der Wende, M. (2009). The New Global Landscape of Nations and Institutions. W: OECD. Higher Education to 2030, Volume 2: Globalisation (17-62). Paris: OECD.

Martens, K. (2007). How to become an influential actor: the comparative turn in OECD education policy. W: K. Martens (red.), New Arenas of Education Governance: the impact of international organizations and markets on educational policymaking (40-65) Basingstoke: Palgrave Macmillan.

Martens, K., Weymann, A. (2007). The internationalization of education policy: towards the convergence of national paths. W: A. Hurrelmann, S. Leibfried, K. Martens, P. Ma- 
yer (red.), Transforming the Golden Age Nation-State (152-172). Basingstoke: Palgrave Macmillan.

Massy, W.F. (2004). Markets in Higher Education. Do they promote internal efficiency?. W: P. Teixeira, B. Jongbloed, D. Dill, A. Amaral (red.), Markets in Higher Education Rhetoric or reality? (13-36). Dordrecht: Springer.

McLaughlin, K., Osborne, S.P., Ferlie, E. (red.) (2002). New Public Management. Current Trends and Future Prospects. New York: .

Merton, R.K. (1968). The Matthew Effect in Science. Science. 159(3810): 56-63.

Mirowski, P. (2013). Never Let a Serious Crisis Go to Waste: How Neoliberalism Survived the Financial Meltdown. London: Verso.

Morrisey, J. (2013). Governing the academic subject: Foucault, governmentality and the performing university. Oxford Review of Educatio.n 39(6): 797-810.

Morrisey, J. (2015). Regimes of performance: practices of normalised self in the neoliberal university. British Journal of Sociology of Education. 36(4): 614-634.

Munck, R. (2009). Neoliberalizm a polityka, neoliberalna polityka. Tłum. P. Listwan. W: A. Saad-Filho, D. Johnston (red.), Neoliberalizm przed trybunatem (101-116). Warszawa: Książka i Prasa.

Musiał, K. (2013). Uniwersytet na miarę swego czasu. Transformacja społeczne $w$ dobie postindustrialnej a zmiany $w$ szkolnictwie wyższym krajów nordyckich. Gdańsk: słowo/obraz terytoria.

Münch, R. (2014). Academic Capitalism. Universities in the Global Struggle for Excellence. London: Routledge.

Naschold, F. (1996). New Frontiers in Public Sector Management. Trends and Issues in State and Local Government in Europe. Berlin: Walter de Gruyter.

Neave, G. (1998). The Evaluative State Reconsidered. European Journal of Education. 33(3): 265-285.

Neave, G. (2011). The Changing „Vision Thing”: Academia and the Changing Mission of Higher Education. Educacao, Sociedade, Cultura. 33: 15-36.

Neave, G. (2012). The Evaluative State, Institutional Autonomy and Re-engineering Higher Education in Western Europe. The Prince and His Pleasure. Hampshire: Palgrave.

Neave, G., Vought, F. van (red.) (1991). Prometheus Bound. The Changing Relationship Between Government and Higher Education in Western Europe. Oxford: Oxford University Press.

Neave, G., Vought, F. van (red.) (1994). Government and Higher Education Relationships Across Three Continents. The Winds of Change. Oxford: Oxford University Press.

Newfield, Ch. (2008). Unmaking the Public University. The Fourty-Year Assault on the Middle Class. Cambridge Mass.: Harvard University Press.

Nixon, J. (2011a). Higher Education and the Public Good. Imagining the University. London: Bloomsbury Academics.

Nixon, J. (2011b). Re-Imagining the Public Good. W: M. Bailey, D. Freedman (red.), The Assault on Universities. A Manifesto for Resistance (59-70). London: Pluto Press.

Nowotny, H., Scott, P., Gibbons, M. (2001). Re-Thinking Science: Knowledge and the Public in an Age of Uncertainty. Cambridge: Polity Press. 
Olssen, M., Peters, M.A. (2005). Neoliberalism, higher education and the knowledge economy: from free market to knowledge capitalism. Journal of Education Policy. 20(3): 313-345.

Paradeise, C., Reale, E., Bleiklie, I., Ferlie E. (red.) (2009). University Governance. Western European Comparative Perspectives. Dordrecht: Springer.

Paradeise, C., Reale, E., Goastellec, G. (2009). A Comparative Approach to Higher Education Reforms in Western European Countries. W: C. Paradeise, E. Reale, I. Bleiklie, E. Ferlie (red.), University Governance. Western European Comparative Perspectives (197-225). Dordrecht: Springer.

Peck, J. (2010). Constructions of Neoliberal Reason. Oxford: Oxford University Press.

Pfeffer, J., Salancik, G. (2003). The External Control of Organizations. A Resource Dependence Perspective. Stanford: Stanford University Press.

Powell, J., Hendricks, J. (red.) (2009). The Welfare State in Post-Industrial Society. A Global Perspective. Dordrecht: Springer.

Power, M. (1994). The Audit Explosion. London: Demos.

Power, M. (1997). The Audit Society. Rituals of Verification. Oxford: Oxford University Press.

Pusser, B., Kempner, K., Marginson, S., Ordorika, I. (red.) (2012). Universities and the Public Sphere: Knowledge Creation and State Building in the Era of Globalization. New York: Routledge.

Rhoades, G. (1997). Managed Professionals. Restructuring Academic Labor in Unionized Institutions. New York: SUNY Press.

Rhoades, G. (2014). Extending Academic Capitalism by Foregrounding Academic Labor. W: B. Cantwell, I. Kauppinen (red.), Academic Capitalism in the Age of Globalization (113-136). Baltimore: The Johns Hopkins University Press.

Rhoads, R.A., Torres, C.A. (red.) (2006). The University, State, and Market. The Political Economy of Globalization in the Americas. Stanford: Stanford University Press.

Rhoten, D., Calhoun, C. (2011). Knowledge Matters: The Public Mission of the Research University. New York: Columbia University Press.

Rooksby, J.H., Pusser, B. (2014). Learning to Litigate. University Patents in the Knowledge Economy. W: B. Cantwell, I. Kauppinen (red.), Academic Capitalism in the Age of Globalization (74-93). Baltimore: The Johns Hopkins University Press.

Ross, A. (2011). Powstanie globalnego uniwersytetu. Tłum. E. Okroy. W: K. Szadkowski, J. Sowa (red.), Edu-factory. Samoorganizacja i opór w fabrykach wiedzy (31-58). Kraków: Wyd. Korporacja Ha!art.

Saad-Filho, A., Johnston, D. (2009). Wprowadzenie. Tłum. P. Listwan. W: A. Saad-Filho, D. Johnston (red.), Neoliberalizm przed trybunatem (13-21). Warszawa: Książka i Prasa.

Salerno, C. (2005). Financing higher education: The economics of options, trade-offs ad dilemmas. W: L. Weber, S. Bergan (red.), The Public Responsibility for Higher Education (181-192). Strasbourg: Council of Europe Publishing.

Sassen, S. (2007). Globalizacja: Eseje o nowej mobilności ludzi i pieniędzy. Tłum. J. Tagnerowicz. Kraków: Wyd. Uniwersytetu Jagiellońskiego. 
Scott, P. (1998). Massification, Internationalization and Globalization. W: P. Scott (red.), The Globalization of Higher Education (108-129). Buckingham: Open University Press.

Scott, P. (2015). Higher Education, the Public Good and the Public Interest. W: O. Filippakou, G. Williams (red.), Higher Education as a Public Good. Critical Perspectives on Theory, Policy and Practice (41-58). New York: Peter Lang.

Shore, C., Wright, S. (1999). Audit Culture and Anthropology: Neo-Liberalism in British Higher Education. The Journal of Royal Anthropological Institute. 5(4): 557-575.

Shore, C., Wright, S. (2004). Whose Accountability? Governmentality and the Auditing of Universities. Paralax. 10(2): 100-116.

Shore, C., Wright, S. (2015a). Governing by numbers: audit culture, rankings and the new world order. Social Antrhopology/Anthropologie Sociale. 23(1): 22-28.

Shore, C., Wright, S. (2015b). Audit Culture Revisited. Rankings, Ratings, and the Reassembling of Society. Current Anthropology. 56(3): 1-10.

Slaughter, S. (2001). Problems in comparative higher education: Political economy, political sociology and postmodernism. Higher Education. 41: 389-412.

Slaughter, S (2014). Foreword. W: B. Cantwell, I. Kauppinen (red.), Academic Capitalism in the Age of Globalization (vii-x). Baltimore: The Johns Hopkins University Press.

Slaughter, S., Cantwell, B. (2012). Transatlantic moves to the market: the United States and the European Union. Higher Education. 63: 583-606.

Slaughter, S., Rhoades, G. (1993). Changes in intellectual property statutes and policies at a public university: revising the terms of professional labor. Higher Education. 26: 287-312.

Slaughter, S., Rhoades, G. (1996). The Emergence of a Competitiveness Research and Development Policy Coalition and the Commercialization of Academic Science and Technology. Science, Technology, \& Human Values. 21(3): 303-339

Slaughter, S., Rhoades, G. (2004). Academic Capitalism in the New Economy. Challenges and Choices. American Academic. 1(1): 37-59.

Slaughter, S., Rhoades, G. (2006). Academic Capitalism and the New Economy. Markets, State and Higher Education. Baltimore: The Johns Hopkins University Press.

Smith, T. (2006). Globalisation. A Systematic Marxian Account. Leiden: Brill.

Strathern, M. (red.) (2000). Audit Cultures. Anthropological studies in accountability, ethics and the academy. London: Routledge.

Szadkowski, K. (2015). Uniwersytet jako dobro wspólne. Podstawy krytycznych badań nad szkolnictwem wyższym. Warszawa: Wyd. Naukowe PWN.

Teixeira, P., Jongbloed, B., Dill, D., Amaral, A. (red.) (2004). Markets in Higher Education. Rhetoric or Reality? Dordrecht: Springer.

Tierney, W.G. (red.) (2006). Governance and the Public Good. New York: SUNY Press.

Toonen, T., (2007). Public Sector Reform in the Knowledge Economy. W: J. Enders, B. Jongbloed (red.), Public-Private Dynamics in Higher Education. Expectations, Development and Outcomes (39-62). Bielefeld: Transcript.

Wacquant, L. (2012). Trzy kroki w stronę historycznej antropologii faktycznie istniejącego neoliberalizmu. Tłum. K. Szadkowski, A. Kowalczyk. Praktyka Teoretyczna. 5: 129-151.

Weber, L., Bergan, S. (2005). The Public Responsibility for Higher Education. Strasbourg: Council of Europe Publishing. 
Wende, M. van der (2011). Global institutions: the Organization for Economic Cooperation and Development. W: R. King, S. Marginson, R. Naidoo (red.), The Globalization of Higher Education (95-113). Cheltenham: Edward Elgar.

Zemsky, R. (2004). Have We Lost the Public in Higher Education? Chronicle of Higher Education. 49(38): B7.

\title{
Thesis on the hybridization of the public and the private in higher education and its consequences. A critique
}

\begin{abstract}
In this text, consists of three separate parts, thesis on the hybridization of the public and the private in the context of contemporary transformation of the higher education sector is presented and problematized. In the first part, the conceptual pair of the public and the private, drawn from the vocabulary of liberal political theory and classical political economy is analyzed in relation with the reality of higher education. In the second, largest section, along with the lines of glonacal method of analysis outlined by Simon Marginsona and Garry Rhoades, the global, national and local processes that contribute to hybridization of the private and the public orders in today's higher education systems are outlined and analyzed in their interrlation. The last part, the summary of the analysis, develops a critique of the thesis on hybridization and points out its analytical and practical limitations.
\end{abstract}

KEYWORDS: hybridization, higher education, the public, the private, higher education research

CYTOWANIE: Szadkowski, K. (2015). Teza o hybrydyzacji tego, co publiczne i tego, co prywatne w szkolnictwie wyższym oraz jej konsekwencje. Próba krytyki. Nauka i Szkolnictwo Wyższe. 2(46): 75-120. DOI:10.14746/nsw.2015.2.3. 